\title{
More than money: The political consequences of compensation
}

\author{
Elsa Voytas ${ }^{\dagger}$
}

August 9, 2021

\section{PRELIMINARY DRAFT}

\begin{abstract}
After political violence, many states compensate victims as part of their approach to transitional justice. Do material reparations change political participation? I argue that receiving material reparations can increase political engagement. I use a multi-method approach to show that surviving victims of the Pinochet dictatorship in Chile who receive a material reparation are more likely to register to vote after being compensated. I substantiate this claim through content analysis of victim testimonies, qualitative interviews, and causal estimates that exploit exogenous variation in the timing of reparations. I find that reparations are capable of persuading resistant populations to engage in politics. Additionally, my results suggest that the noneconomic component of reparations payments is particularly valued by recipients, as victims use this transitional justice experience to update their views about the state. In particular, victims value the acknowledgment attached to compensation and the consistency with which their payments are received. These findings suggest that relatively small transfers can reengage victims whose voices were previously unheard in formal politics and that analyses of the consequences of violence should account for experiences with transitional justice policies. From a policy perspective, the results are important for societies implementing transitional justice policies in the hopes of achieving long-lasting peace and preventing reversions to violence.
\end{abstract}

*This work was made possible with support from the United States Institute of Peace and Princeton's Bobst Center for Peace and Justice and Project in Latin American Studies. I am grateful to Carrie Barnett, Ben Crisman, Andy Guess, Alisha Holland, Will Horne, Gaileu Kim, Dean Knox, James Mao, José María Rodriguez-Valadez, Jake Shapiro, Manu Singh, Brandon Stewart, John Marshall, Deborah Yashar, and participants at PELA 2020 for their feedback on this project. Note: previous versions of this paper were circulated under the titles "What can money buy?" and "What can reparations do?"

†Princeton University. Email: evoytas@princeton.edu. 


\section{Introduction}

Material reparations, or compensation administered to victims from the state, is a common transitional justice policy. As shown in Figure 1 reparations were administered 41 times between 1978 and 2007 (Olsen et al. 2010). These include \$4,000 payments to the 18,000 victims who testified before South Africa's Truth and Reconciliation Commission, compensation for 24,000 victims from Argentina's military dictatorship, and reparations for nearly 10,000 victims of Morocco's "years of lead."1 Since 2007, additional policies have been implemented and fiercely debated in societies with turbulent pasts, including the United States. ${ }^{2}$ These policies are inherently economic, though they can confer a powerful symbolic meaning, particularly when distributed by the state responsible for past harm. Do material reparations change political participation? Are recipients influenced by reparations' symbolism and/or economic stimulus?

To gain traction on this question, I examine material reparations in Chile, the site of a 17-year long military dictatorship under the leadership of General Augusto Pinochet. Between 1973 and 1990, the dictatorship killed more than 3,000 Chileans (Rettig Report) and tortured nearly 40,000 (Valech Report), over 22,000 of whom have since been compensated. I utilize a multi-method approach to examine the link between material reparations and engagement with the state. Reparations are not random, so to establish causal estimates, I leverage exogenous variation in the timing of payments to show that a year after reparations start, surviving victims have more than a 10 percentage point increase in registering to vote compared to those not yet compensated. I argue that the increase stems not solely from the economic component of reparations but from the symbolic interpretation victims attach to them. In-depth qualitative interviews and victim testimonies support this claim. These findings suggest that tran-

\footnotetext{
${ }^{1}$ See https://www.ictj.org/our-work/transitional-justice-issues/reparations.

${ }^{2}$ For example, in 2017, the Canadian government made reparations available for victims of its "gay purge" (see https://www.nytimes.com/2017/11/28/world/ canada/canada-apology-gay-purge-compensation.html) while reparations for descendants of slaves in the US has become a topic of debate in the 2020 Democratic primary (see https://www.vox.com/policy-and-politics/2019/3/11/18246741/ reparations-democrats-2020-inequality-warren-harris-castro).
} 
sitional justice, defined as the policies states implement to confront histories of human rights abuses and political violence, shapes political behaviors in post-violence contexts. In particular, I suggest that transitional justice is capable of redirecting the effects of violence exposure and heightening desires to engage with the state. I highlight a symbolic mechanism behind this effect, as the transfer is seen as acknowledgment of past transgressions. Engaging with the state during the reparations process also allows victims to learn about its responsiveness and the efficacy of participating in politics (Soss 1999; Campbell 2003; Mettler 2005).

This finding is valuable for understanding the legacy of violence and for post-conflict societies seeking to augment prospects for durable peace and societal reconciliation. Research on the political consequences of violence emphasizes different behavioral responses to conflict exposure. Some scholars posit a withdrawal effect, where individuals affected by post-traumatic stress retreat from political life (Bautista 2016; Ehlers and Clark 2000; Gavlovski and Lyons 2004; Miller and Rasmussen 2009). Others suggest that victimization increases political participation such as attending community meetings, voting, and political group membership (Bellows and Miguel 2006; Blattman 2009; Gilligan et al. 2014). I suggest that transitional justice plays a mediating role in the relationship between violence and behavior and can help explain heterogeneous political participation after violence across time and within groups. Thus, analyses of the long-term effects of violence should account for transitional justice experiences.

These results reveal that transitional justice participation can affect whose voices are heard and represented in new democracies. I join a growing number of scholars examining transitional justice at the micro-level (Aguilar et al. 2011; Cilliers et al. 2016; Gibson 2004, 2006, Brounéus 2010). In the realm of reparations, most work has focused on reparations preferences (Espinoza Cuevas, Ortiz Rojas, and Rojas Baeza 2003; Laplante and Theidon 2007; David and Choi 2005; Viaene 2010) and victims' attitudinal responses (Sveaass and Sønneland 2015; Luzzi 2014, 2018; Pham et al 2016). Behaviorally, I find an increase in political participation among a subset of victims resistant 
to engage in politics. Focusing on how transitional justice affects behaviors shows that in certain cases and contexts, policies can reengage portions of the population previously sidelined from formal politics. Reparations increase the representation of this portion of the population. The current article complements country-level work which has documented transitional justice's capacity to affect macro-outcomes, such as rule of law, human rights protection, and democratic consolidation (Dancy and Thoms 2021; Sikkink 2011; Olsen et al. 2010; Ferrara 2015; Gibson 2004; Wiebelhaus-Brahm 2010). I probe the foundations of these concepts and suggest a possible bridge between these outcomes and citizen attitudes and behaviors.

In addition to advancing transitional justice and reparations' scholarship, this work has implications for political participation more broadly. While traditional participation models often focus on the explanatory variables of individual resources, such as money and knowledge, I suggest that state interactions during transitional justice are capable of structuring political participation. This accords with policy feedback scholarship which suggests that public policies can influence political behaviors, including trust in and willingness to engage with the state (Soss 1999; Campbell 2003; Mettler 2005; Weaver and Lerman 2010; Bradford et al. 2014; Meares 2017; Kruks-Wisner 2018). I extend these insights to the realm of transitional justice, where engagement with state-run material reparations affects subsequent participation patterns.

This paper proceeds as follows. In section 2, I develop my theoretical approach to explain how reparations alter political participation, highlighting how compensation has an economic and noneconomic component, both of which could increase political participation. Section 3 describes material reparations in the Chilean case, where surviving victims first became eligible to receive reparations in 2005 after testifying before a truth commission. In section 4, I present my empirical strategy and results. Relying on a multi-method approach and exogeneity in the reparations approval process, I find that reparations increase surviving victims' propensity to register to vote and present evidence in favor of a symbolic mechanism. Section 5 concludes with implications for 


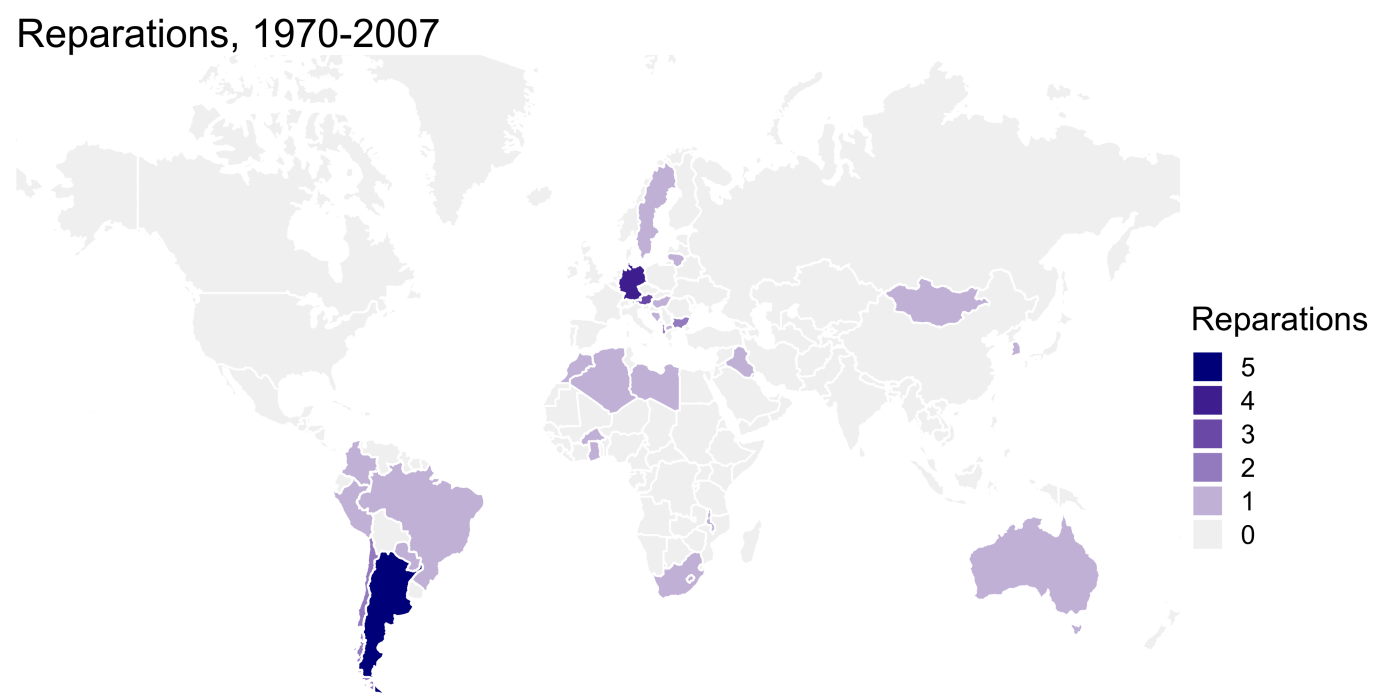

Source: Transitional Justice Collaborative
Notes: Map shading corresponds to number of reparations policies that have been implemented per country from 1970-2007 according to data housed by the Transitional Justice Database Project.

reconciliation after violence and directions for future research.

\section{Political participation after violence}

How does political participation change after violence? While studies of the legacies of violence have proven useful in documenting withdrawal and activation in the aftermath of violence, they are less helpful in explaining how responses vary within classes of victims and change over time. Meanwhile, increasingly, studies highlight heterogeneous reactions among victim populations. Studies find that Mexican victims of criminal violence are most likely to be politically active when they are embedded in strong social networks (Dorff 2017) and that in Colombia, those victimized by state groups are less likely to participate than victims whose perpetrator was not linked to the government (Voytas and Crisman 2021). And Moncada (2018) notes that in considering downstream responses, ongoing interactions between victims and criminals warrant attention. The theme emerging from this line of inquiry is that there are dynamic and nonuniform patterns in political participation among victims of violence. I 
argue that some of the variation in the desire to reengage politically can be attributed to transitional justice participation, and that transitional justice mediates the relationship between exposure to political violence and subsequent political participation.

Forms of political participation differ in what they require of citizens and what citizens intend from engaging in them. I distinguish between institutional and extrainstitutional political activity. Institutional political participation refers to activities such as voting, that take place within the bounds of the formal political system and require intentional and identifiable engagement with the state. Populations victimized by state entities might be resistant to this type of activity because of fear, skepticism, and distrust. Indeed, existing work finds that after violence, citizens express lower levels of generalized trust (De Luca and Verpoorten 2015; Kijewski and Freitag 2016; Rohner and Zilibotti 2011), lower approval of political actors (Gates and Justesen 2016), and decreased trust in the national government (De Juan and Pierskalla 2016). I consider how attitudinal shifts such as these manifest behaviorally in one example of institutionalized political participation: registering to vote. In contrast to institutional political participation, extrainstitutional activity, such as protest behavior, typically does not require individuals to engage directly with the state. The link between reparations and extrainstitutional political behavior remains a topic for future research.

How might reparations change institutional political engagement and voter registration in particular? I argue that compensation can increase voter registration for a number of reasons. I distinguish between the economic and symbolic dimensions of reparations, either or both of which might change political participation. I consider these possibilities with my empirical strategy.

Political participation is costly (Downs 1957; Verba, Nie, and Kim 1978). Canonical accounts of political participation emphasize the role of socio-economic endowments and individual economic resources (Conway 1991). Victimization can reduce resources, in the form of losing a job, having education interrupted, or missing rent payments during internment. These losses can accumulate, causing reduced political 
activity. Reparations' economic component could help restore some of the material losses suffered as a result of victimization by offering a "development boost" that allows citizens to return to normal life activities, including those political in nature (De Grieff 2008). Existing analyses of targeted cash transfer government programs show that they increase voter turnout (De la O 2013; Pop-Eleches and Pop-Eleches 2012), though these programs were not directed toward victims of violence but rather individuals with low socio-economic statuses. Still, if income increases drive political engagement, reparations might increase institutional political activity through this economic pathway, and larger amounts would be more effective than smaller.

On the other hand, human rights violations can exact social and psychological consequences. Victims report feeling disempowered (Bies and Tripp 1996) and disrespected (Lind and Tyler 1988). Injustice can threaten feelings of belonging (Lind and Tyler 1988) and moral principles about right and wrong (Folger 1988). Scholars suggest that injustice responses like reparations serve a symbolic function that helps address these concerns (Desmet et al. 2010; Tyler and Blader 2003). The symbolic mechanism is akin to Pierson (1993)'s "interpretive effects" defined as "the impact of policies on the cognitive processes of social actors." Though conventional economic approaches suggest money is an impersonal commodity with a quantitative interpretation, individuals might attach symbolic meaning to money beyond its economic value (Belk \& Wallendorf 1990; Krueger 1986; Zelizer 1994). This may be because material transactions are embedded in social systems, and due to their interactional and relational nature, can be used to create and reshape social ties (Carruthers \& Espeland 1998; Zelizer 1989, 1994). Compensation after violence recognizes wrongdoing, and may be perceived as more "costly" than verbal acknowledgment. In this way, compensation is imbued with informational signals about victim status and identity. It allows recipients to infer whether they, and the groups they belong to, are perceived positively by the state.

Payment itself can hold meaning, but individuals' experiences within the policy process may also shape their desire to engage in the future (Soss 1999, Campbell 2003, 
Mettler 2005). This is because interactions with the state and its institutions provide opportunities for victims to update their perceptions of the state previously responsible for waging violence against them. While obtaining reparations, victims learn whether the state treats them with dignity and whether engagement is efficacious. As Tyler and Blader (2003) and Bradford et al. (2014) suggest, procedures carried out by authorities - and specifically the fairness of these procedures - can convey that subgroups (victims) are valued and included by the superordinate group (nation). The reparations process might alleviate fear toward the state and reduce the psychological costs of participating politically. Though these experiences take place with certain state agencies and representatives, the experiences and lessons learned can translate to other facets of government and modes of participating (Lawless and Fox 2001).

The symbolic mechanism thus captures a number of micro-mechanisms. It may be that the policy experience - and the state's reliability and consistency in fulfilling its promise to victims - generates feedback effects that drive future participation. It could also be that acknowledgment itself spurs political engagement, or that the process of applying for and receiving reparations mitigates fear of state interaction and lowers the cost of participation. These micro-mechanisms share the feature that they are non-economic in nature and go beyond the pure dollar value of compensation. This commonality distinguishes them from economic pathways. The relative prevalence of these micro-mechanisms will be further explored in future research.

I have laid out two channels through which institutional political activity might change upon receiving compensation. These pathways have distinct observable implications, and the prevalence of each can be considered by analyzing salient concerns (economic vs. socio-psychological) prior to the policy, perceptions of the policy, and behavioral responses after the policy. Still, that participation will increase is not a foregone conclusion. Reparations might not affect, or could even decrease, levels of institutional political behavior. For example, if levels of material reparations are small and do not sufficiently address victim grievances or even exacerbate feelings of injustice, they 
could further elevate the psychological cost of engaging with the state. This could be the case if victims and family members feel like reparations are "blood money" that do not adequately address their desires and needs (Luzzi 2014). In this case, reparations could create a "self-undermining" policy backlash, wherein individuals withdraw from the political system they see as unjust (Jacobs and Weaver 2014). Similarly, if the process of receiving reparations suggests that the state is unresponsive or incapable of addressing victim needs, reparations may cause victims to disengage.

I argue, however, that even if victims feel as though reparations policies are inadequate or incomplete, they can nonetheless serve a symbolic function that reduces the risk and changes the nature of state interactions. The institutional nature of the policy suggests that the formal political system is a way to enact change and to achieve victories for victims, spurring political engagement. The preceding discussion generates a central hypothesis and two distinct observable implications associated with each mechanism:

- Hypothesis 1: Reparations will increase political participation.

- Economic observable implication: Victims will discuss harms in economic terms. Political participation will increase with the size of reparations payments.

- Symbolic observable implication: Victims will discuss their harms in sociopsychological terms and perceive reparations as having a symbolic value.

\section{Material Reparations in Post-Repression Chile}

I test my expectations with the material reparations policy in post-dictatorship Chile. State-run compensation has been established for family members of those killed and surviving victims of torture during the Pinochet era. As in Chile, many states that failed to protect citizens or directly committed violations have invoked reparations policies in the post-violence period (see 1. Though these contexts should be studied in their own rights, investigating the Chilean case can begin to generate hypotheses about behavioral responses to compensation elsewhere. It is worth noting Chile's high degree of state capacity, which may lead to more reliable disbursal of compen- 
sation and high expectations of the returns to political participation, making political engagement more likely. On the other hand, during the period studied, political cynicism was relatively high in the Chilean context, with weak levels of partisan affiliation (Luna 2010), perhaps muting the effects of compensation on political engagement. I return to the topic of generalizability in the conclusion, but note that the extent to which evidence from Chile generalizes is worthy of future research.

In Chile today, debates about the past shape contemporary politics and have generated mass political movements. In 2019, large-scale protests erupted over a series of economic issues. Protests and grievances expanded, and citizens demanded that the Pinochet-era constitution be replaced. In a 2020 referendum, Chileans voted for replacement. Investigating how transitional justice policies function in atmospheres like this can generate new insights about the legacies of violence.

Registering to Vote

Registration was reopened in post-Pinochet Chile in early 1987 before the 1988 plebiscite where voters indicated whether or not they supported an end to Pinochet's rule. To register, citizens had to go to an Electoral Service office where a state employee added them to the official voting registry. Registering before 2012 was voluntary, but after registering, voting in future elections was mandatory. This requirement makes registration highly predictive of subsequent turnout, particularly since thoes failing to turnout were fined up to $\$ 220.00$ USD. ${ }^{3}$

What did it mean to register to vote? The general population had been unable to vote for their leader since 1970. For victims, this period coincided not only with their experience of violence but a more general lack of outlets for political expression (political parties were banned). Registering to vote in this context - and voting against Pinochet - could be empowering, as numerous interviewees noted. For example, when recalling her voter registration, one respondent told me: "For me, it was an emotional experi-

\footnotetext{
${ }^{3}$ Exceptions included illness, being out of the country, being more than $200 \mathrm{~km}$ from voting place, or other reason deemed eligible by a local judge.
} 
Figure 2: Surviving victim registration trends

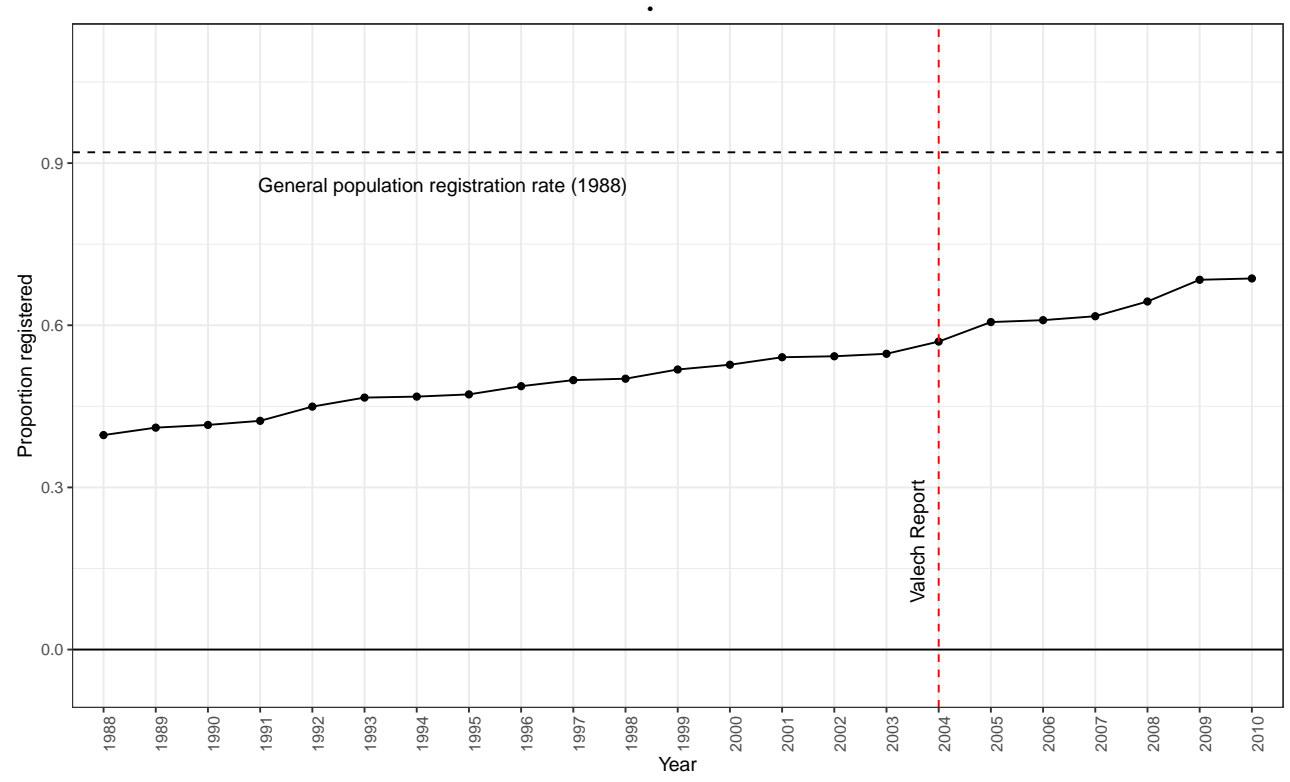

Notes: Points correspond to percentage of surviving victims registered to vote. Y-axis portrays years, from 1988 when registration reopened to 2010, before registration became automatic. Dashed red line indicates the Valech Report release. Because longitudinal registration data among the general public eligible to vote in 1988 is unavailable, the dashed black line indicates the lower bound - the 1988 rate.

ence. It was so exciting...And when the "No" won, I cried and said 'Finally, finally we are going to know what happened to our family."'4 But it could also be risky. Even after Pinochet was ousted, he retained a political position and many in his administration remained powerful, creating the perception that the government might be hostile toward victims and that it could be dangerous to engage in a political act with a public record. As an interviewee noted: "The return to democracy was full of agreements that let Pinochet and the entrepreneurs control everything. In the end, they tricked us. ${ }^{5}$ In a climate of fear and distrust, registering to vote and voting were unique but potentially risky ways to express discontent with Pinochet and his allies.

For the 1988 plebiscite, $92 \%$ of the voting age general population registered to participate and $88.51 \%$ turned out to vote. It was different for surviving victims. Figure 2 plots the proportion of surviving victims that registered over time. It is not possible to calculate a comparable trend for the general population, since new, younger individuals become eligible to vote in the general population, and the public's rate could

\footnotetext{
${ }^{4}$ Personal interview, conducted June 2, 2019, Buin, Chile

${ }^{5}$ Personal interview, conducted June 4, 2019, Buin, Chile
} 
go up or down while survivors' rate can only increase. However, the dashed black line can be interpreted as a lower bound of the relevant figure, which corresponds to the turnout as a percentage of the voting age population in the 1988 plebiscite $(92 \%)$. The gap between victims, whose registration rate increases from $41 \%$ in 1988 to $69 \%$ in 2012, and the general population suggests that the former were more resistant to return to institutional political activity (see also Bautista 2016). The plot further suggests that surviving victims exhibit surprising heterogeneity as a group, some which may be traced to transitional justice participation.

\section{Collecting Reparations}

This paper focuses on surviving victims, who constitute the vast majority of reparations recipients in Chile (92\%). ${ }^{6}$ Several truth commissions have taken place since the democratic transition. The first, the Rettig Commission, reported those who had been killed or permanently disappeared for political reasons. Their family members (spouses, parents, and children) could then receive monthly reparations payments. Torture survivors lobbied for a truth commission to investigate non-lethal crimes. In 2004, President Lagos convened the Valech truth commission. Surviving victims who testified were listed in the commission's final report and were eligible to receive reparations. In 2010, President Bachelet reopened the commission, allowing more survivors and family members to testify. To be considered a surviving victim, individuals had to have been detained for political reasons and torture had to have taken place in one of the 1,200 official detention centers in Chile. Only those who testified could receive compensation. Victims who were listed in the Valech Report had to present themselves at their local Instituto de Previsión Social (Social Security Institute, hereafter IPS) office to begin receiving reparations. I identify those 22,513 surviving victims who received compensation as of 2018 using an original dataset of surviving victims and information on their compensation timetable. The schedule of payment amounts, administered monthly and ranging from \$260-297 USD is equal to about half of monthly

\footnotetext{
${ }^{6}$ I do not combine family members and surviving victims because I do not assume that their patterns of political participation and response to transitional justice policies will be similar.
} 
the minimum wage and is depicted in Table A1.

\section{Evidence on Effect of Reparations}

To investigate how material reparations shape political participation, I study several related questions. First, what are victims' concerns before reparations? Second, to what extent does receiving a reparation shape political activity? And finally, why might surviving victims participation change? Utilizing different methods to answer these questions triangulates across different types of data, providing a richer picture of post-repression complexities than is possible with a single-methodology study.

\section{Evidence on Victim Concerns}

The extent to which compensation helps balance the scale of justice concerns its ability to address the salient consequences of the original transgression (Cropanzano et al. 2001; Mullen and Okimoto 2015). Social psychologists suggest that concerns might be instrumental, when victims lose power or resources, or more symbolic, when incidents threaten an individual's identity or deeply held moral convictions. This framework suggests that understanding the impact of reparations requires understanding salient concerns elicited by the original injustice and considering whether reparations effectively address those concerns. But understanding victim concerns prior to reparations poses challenges. One could ask victims today what their concerns were pre-2005, but they may not remember, and even if they did, their responses might be subject to recall bias. To get around this concern, I turn to survivor testimonies collected in the years immediately preceding the Valech truth commission.

In the early 2000s, an NGO called Corporación de Promoción y Defensa de los Derechos del Pueblo (The Corporation for the Promotion and Defense of the Rights of the People, hereafter CODEPU), collected nearly 1,000 testimonies to "illustrate the grav- 
ity and magnitude" of torture committed during the Pinochet era and persuade the government to open an official truth commission (Rojas et al. 2002). CODEPU asked victims to provide personal information (name, national identification number, age, and profession) and recount their torture experiences. Specifically, they were asked:

- Who detained you?

- Where did they take you?

- What type of torture were you subjected to?

- Who conducted the torture? For how long?

- Who was detained with you?

- Why did they say they were conducting the torture?

- What type of consequences has the torture had? ${ }^{7}$

CODEPU delivered these victim testimonies in a series of reports: the first, containing roughly 500 testimonies was published in December 2002; the second, with an additional 500 testimonies was published in December 2003; and the third, which included denunciations of perpetrators, was published in May 2004. I perform content analysis on the first two, totaling 1,004 testimonies, to systematically analyze how individuals frame their victimization. These testimonies, published just months before reparations began, constitute a "pre-treatment" expression of survivors' thoughts about the harm they suffered and, sometimes, their desires for addressing it. This exercise serves two descriptive purposes: first, it facilitates exploration of victims' salient concerns; second, it allows me to categorize torture's consequences, which can offer hints about why reparations affect recipients. In particular, I can explore the prevalence of references to economic losses, which might suggest that reparations would help address lost resources and facilitate individuals' return to normal life and to psychological harm, which might suggest that recognition from the state would be meaningful.

As Figures A1 and A2 suggest, automated text analysis methods reflect that the bulk of testimonies recount individuals' arrest and detention, describing where they were

\footnotetext{
${ }^{7}$ Translation by the author. According to the publication released by CODEPU, victims were asked "nombre, cédula de identidad, edad, profesión, la fecha en que la persona fue detenida. Se preguntaba ¿quiénes la detuvieron?, ¿dónde la trasladaron?, ¿a qué tipo de técnicas de tortura la sometieron?, ¿quiénes las practicaron?, ¿por cuánto tiempo?, ¿quiénes estuvieron detenidos con él o ella?, ¿en qué condiciones?, ¿fue sometido a proceso?, ¿qué cargos le hicieron?, ¿qué tipo de secuelas dejó la tortura?"
} 
Table 1: Excerpts from testimonies corresponding to each category.

\begin{tabular}{l|l} 
Category & Example text \\
\hline Economic & $\begin{array}{r}\text { - "The greatest suffering was borne by my children who were } 6 \\
\text { and } 4 \text { years old. They were left homeless without money, without } \\
\text { medical assistance, etc. Little by little my wife sold the furniture } \\
\text { to buy food for them." } \\
\text { - "I lost my only job up to that point. After that, I had to work odd } \\
\text { jobs. If I'd kept my job, I'd have a full pension and never would } \\
\text { have had these economic troubles..." }\end{array}$ \\
\hline Psychological & $\begin{array}{l}\text { - "I suffer from pent-up rage, fear in the presence of police, feelings } \\
\text { of persecution, and insecurity in certain situations." }\end{array}$ \\
\hline Physical & $\begin{array}{l}\text { - "I "Physical consequences include permanent pain in my neck, } \\
\text { hands, knees, and feet." } \\
\text { - "I still have a scar in the left dorsal region as a result of the blows } \\
\text { I received during my detention." }\end{array}$ \\
\hline
\end{tabular}

Notes: Testimonies from Corporación de Promoción y Defensa de los Derechos del Pueblo (CODEPU) "Testimonios de Tortura en Chile" accessed in the Museo de la Memoria y los Derechos Humanos Centro de Documentación (CEDOC), Santiago, Chile.

taken and the violence they suffered. But most testimonies also discuss the consequences of torture and how victims hope these crimes will be addressed through state policies. To categorize references about the consequences of torture, I read through each testimony and manually hand-coded whether it made reference to 1) economic, 2) psychological, and/or 3) physical harm (see examples in Table 1). I then summed up the total number of victims that discussed economic consequences. Roughly $17 \%$ of total testimonies included references to economic hardships faced as a result of torture. Significantly more individuals framed their suffering in physical or psychological manners. Figure 3 presents a Venn diagram showing how individuals discussed their victimization. Note that 485 ( $48 \%$ of) victims did not refer to their victimization in economic, physical, or psychological ways but focused exclusively on the details of their detention and torture. The figure shows that individuals are most likely to discuss the physical consequences of torture, followed by the psychological consequences. 173 surviving victims do refer to effects on their material wellbeing, but they comprise a minority of those offering testimonies, and most have additional noneconomic salient concerns. 
Figure 3: Contents of victim testimonies.

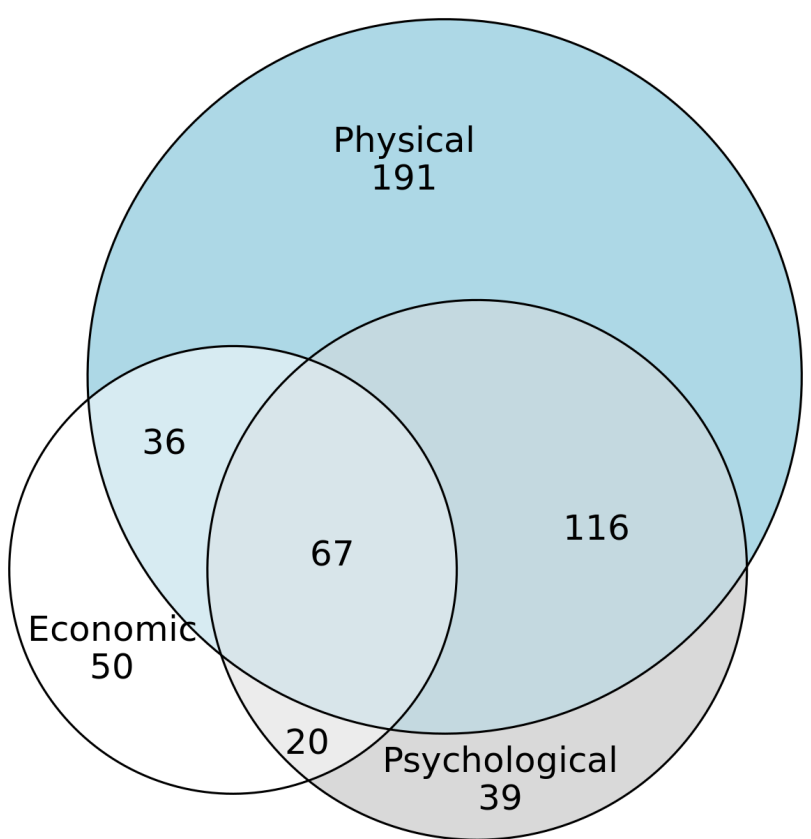

Notes: Testimonies from Corporación de Promoción y Defensa de los Derechos del Pueblo (CODEPU) "Testimonios de Tortura en Chile" accessed in the Museo de la Memoria y los Derechos Humanos Centro de Documentación (CEDOC), Santiago, Chile.

\section{Evidence on Registration Rates}

The text data suggests that only a minority of victims fixate on economic losses, yet material reparations are one of the most common forms of transitional justice. Do they work, and if so, is it because of their economic dimension, or in spite of it? I proceed with quantitative evidence to assess the link between receiving reparations and political activity.

I begin by constructing an original dataset of surviving victims, reparations' receipts, and voter registration. Through Chile's Transparency Law, I requested fine-grained reparations data from IPS. For the 22,513 surviving victims collecting monthly reparations, these individual-level data include the date when IPS approved a surviving victim's solicitation for reparations, her full name, birth date, gender, and province of residence. Table 2 documents summary statistics for these key variables. I link these data to voter registration files, which include the date an individual registered to vote until late 2010 when an electoral reform law made registration automatic. The voter 
registration data, formerly available on the Electoral Commission's (SERVEL) website, can be linked to reparations and victim data by merging on an individual's name and national identification number. The final dataset facilitates novel analysis of connections between victimization, transitional justice, and political participation.

Table 2: Summary statistics for demographic, independent, and dependent variables.

\begin{tabular}{|c|c|c|c|c|}
\hline \multirow[t]{2}{*}{ Variable } & \multicolumn{2}{|c|}{ Total sample } & \multicolumn{2}{|c|}{ Narrowed sample } \\
\hline & Mean & Range & Mean & Range \\
\hline Observations & 22,513 & & 5,213 & \\
\hline Age & 57 & $17-94$ & 55 & $17-84$ \\
\hline Gender & $\begin{array}{c}\text { 17.5\% Female } \\
82.5 \% \text { Male }\end{array}$ & & $\begin{array}{c}19.3 \% \text { Female } \\
80.7 \% \text { Male }\end{array}$ & \\
\hline Urban & $84.5 \%$ & & $85.2 \%$ & \\
\hline Provinces & $\begin{array}{c}39.8 \% \text { Santiago } \\
6.6 \% \text { Concepción } \\
4.9 \% \text { Valparaíso }\end{array}$ & & $\begin{array}{c}\text { 46.2\% Santiago } \\
5.9 \% \text { Concepción } \\
5.2 \% \text { Valparaíso }\end{array}$ & \\
\hline Reparations approved (date) & $08 / 2007$ & $03 / 2005-06 / 2018$ & $06 / 2005$ & $03 / 2005-09 / 2010$ \\
\hline Voter registration (date) & 06/1993 & $2 / 1987-9 / 2010$ & $10 / 2007$ & $4 / 2005-9 / 2010$ \\
\hline
\end{tabular}

Notes: Total sample refers to all reparations recipients. Narrowed sample refers to those used in empirical analysis (unregistered voters in 2005). Information obtained via author request to IPS and historic SERVEL website.

Table 3: Sample population

\section{Registering to Vote}

Before 2005 After 2005 or never

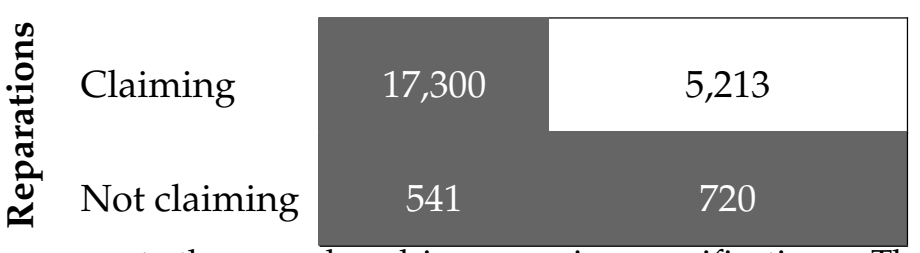

Notes: The white cell represents those analyzed in regression specifications. The dark grey cells are omitted from all analyses. Information obtained via author request to IPS.

To examine whether reparations shape political activity I must first address possible selection problems. Because reparations aren't randomized in a controlled experiment, the challenge is identifying the relevant counterfactual for those receiving reparations payments at any given time. First, I restrict my analysis to only those who had not yet registered to vote when reparations began in 2005. Not only is this the subset of the population who logically could be influenced to register to vote by reparations, it is a group of surviving victims who could have registered to vote for nearly two 
decades before reparations, but opted not to. These victims were reluctant to engage in institutional politics, and consequently, their voices were absent from formal political channels when reparations began. They thus constitute an important group when it comes to democratic representation and enfranchisement.

A straightforward approach would be comparing unregistered voters claiming reparations with unregistered voters not claiming reparations. Figure A3 shows that victims receiving reparations register at higher rates after being compensated. But those who do not visit IPS in-person to claim their reparations might differ systematically from those who do visit IPS, making this group a poorly suited counterfactual. For example, one interviewee noted that those who do not claim their reparations tend to be poorer and less informed than those who do. Additionally, those who do claim may already have higher levels of trust in the government or political activity, which drives both their effort to claim a payment and subsequently register to vote, making establishing the causal effect of reparations difficult. As such, I next restrict the sample to only those unregistered voters who eventually did claim their reparations payments (the white cell in Table 3). Table 2 portrays how these surviving victims compare to the total population. For the subsequent analysis, I thus focus on surviving victims reluctant to engage in formal politics but who participate in this transitional justice program, rather than victims with histories of voting and those who do not participate in this program. Among this group, I exploit differences in the timing of receiving compensation. In short, I model how reparations affect the probability of registering to vote among unregistered voters who eventually receive reparations payments.

Identification among this sub-sample might still be threatened if those whose reparations payments begin earlier or later differ in systematic ways. To address this concern, I utilize the bureaucratic approval process which induces randomness in the timing payments begin. The idiosyncratic and unpredictable approval process helps ensure that the administration of treatment - which here is the time individuals receive their first reparation - is not correlated with other individual-level characteristics and there- 
fore that treatment is allocated in an "as-if" random fashion.

When surviving victims and family members choose to visit an IPS office to prove their identity, IPS employees initiate a technical, multi-staged approval process. At this point, the process is out of victims' hands. According to qualitative interviews conducted by the author, this process could vary in length, largely due to idiosyncratic considerations: IPS office workload (IPS also administers other pensions and benefits for workers and retirees among the general population), holidays, efficiency of certain employees, absences by certain employees, etc. Once approved, payments begin the subsequent month. This process takes three months on average, but can be quicker or continue upwards of a year. ${ }^{8}$ The bureaucratic process that underlies reparations payments provides an entrypoint to analyze how differences in timing of payments which arise not due to case-specific considerations but to exogenous factors - influence subsequent patterns of political behavior. I use this approval date as a starting point, estimating the likelihood of registering to vote in the 12+ months thereafter. Once an individual is approved, I consider them to be "treated," and this status cannot be reversed. I assume that those approved earlier or later serve as plausible counterfactuals for one another. Those approved before and after the median approval date are similar in age, gender, and the urban/rural classification of their community (see Table A3).

I use an event study difference-in-differences framework to estimate the effect of reparations payments (Jacobson, LaLonde, and Sullivan 1993; McCrary 2007). I construct a monthly panel data set of individuals who receive compensation between 2005 (when payments start) and late 2010 (when the last voter registry was published before registration became automatic), meaning that I focus on individuals listed in the first Valech Report, since the second was not released until 2011. Reparations' approvals - and the month payments begin - are staggered across individuals and across time. I control for time-invariant province-specific factors ${ }^{9}$ (province fixed effects) and country-wide factors that are common across provinces (month-year fixed effects). Time fixed effects

\footnotetext{
${ }^{8}$ Personal interview, conducted April 15, 2019.

${ }^{9}$ Provinces are an administrative unit in Chile. There are 56 in the country.
} 
Table 4: Modeling the Effects of Reparations on Voter Registration

\begin{tabular}{lc}
\hline \hline \multicolumn{2}{c}{ Outcome: Registering to Vote } \\
\hline Approved & $0.0435^{* * *}$ \\
& $(0.007)$ \\
Age & 0.0006 \\
& $(0.000)$ \\
Female & -0.007 \\
& $(0.01)$ \\
\hline Province FE & \\
Year month FE & Yes \\
Individuals & Yes \\
$R^{2}$ & 5,213 \\
${ }^{*} p<0.05 ;{ }^{* *} p<0.01 ;{ }^{* * *} p<0.001$ & 0.092 \\
\hline
\end{tabular}

Notes: Rows correspond to coefficients from respective variables. Heteroskedasticity Consistent Robust Standard Errors Clustered at the Individual level in parentheses.

reduce the likelihood that time trends in registration, such as boosts caused be election drives, drive my results. This specification allows me compare subpopulations of treated and untreated individuals within the same province at a given month in time while simultaneously controlling for individual-level factors. I first use a static event study regression (Sun and Abraham 2020) and estimate the average treatment effect of the treated, averaged over all post-treatment months, with province- $\left(\phi_{l}\right)$ and monthyear-specific characteristics $\left(\gamma_{t}\right)$ as well as a vector of individual covariates $\left(X_{i}\right)$ :

$$
Y_{i t}=\alpha+\gamma_{t}+\phi_{l}+\text { Bapproved }_{i t}+X_{i} \delta+\varepsilon_{i t}
$$

where approved $_{i t} \equiv 1\left[t \geq \bar{t}_{i}\right]$ is an indicator for any month $t$ from the month in which $i$ 's reparations are approved, $\bar{t}_{i}$. Heteroskedastic consistent standard errors are estimated at the individual-level. Results from this specification are presented in Table 4 and suggest that receiving a reparation is linked to an average 4.4 percentage point increase in the propensity to register to vote $\left(\hat{\beta}\right.$ approved $\left._{i t}=0.044, p<0.001\right)$.

Equation 1 computes a weighted cumulative effect of registering to vote, given that an individual received a reparation. Now, I estimate the effects in each period following treatment by estimating monthly effects $T$ months after reparations' receipt. I utilize 
a dynamic specification that estimates the average treatment effect on the treated (Sun and Abraham 2020). This design can provide a reliable causal estimate in the absence of preexisting trends before treatment. I assess the validity of this identifying assumption by estimating treatment effects in the months preceding payment and looking for systematic anticipation effects. To increase the robustness of the estimation, I include individual-level factors (age and gender). Heteroskedasticity-robust standard errors are clustered at the individual level. I thus estimate:

$$
\begin{gathered}
Y_{i t}=\alpha+\gamma_{t}+\phi_{l}+\underbrace{\sum_{\tau=-6}^{-1} \beta_{\tau} 1\left[t=\bar{t}_{i}+\tau\right]}_{\text {leads }}+\underbrace{\beta_{1} 1\left[t=\bar{t}_{i}\right]}_{\text {immed. effect }}+ \\
\underbrace{\sum_{\tau=1}^{T-1} \beta_{\tau} 1\left[t=\bar{t}_{i}+\tau\right]+\beta_{\tau} 1\left[t \geq \bar{t}_{i}+T\right]}_{\text {lagged effects over time }}+X_{i} \delta+\varepsilon_{i t}
\end{gathered}
$$

The $\beta$ coefficients from this specification are captured by a set of indicator variables for each month starting 6 months before reparations and extending 12 months after ${ }^{10}$, omitting the month approval is secured. Jointly, they correspond to each observation's timing relative to approval. These capture the monthly treatment effect of reparations on registration by estimating the difference between "treated" (i.e. people receiving compensation in a particular month) and "control" groups (i.e. people not yet receiving compensation) at any given month $t$ relative to the same difference at baseline. $\beta_{1}$ is the immediate effect of reparations, in the month after approval when payments start. $\beta_{2}, \ldots, \beta_{T}$ correspond to monthly effects after approval (estimated up to 12 months after approval). $\beta_{T}$ captures the average effect from month $T$ and beyond (i.e. after 12 months). Finally, $\beta_{-6}, \ldots, \beta_{-1}$ correspond to effects before the distribution of payments, which test for divergent pre-trends. $X_{i}$ includes a vector of individual-level covariates. ${ }^{11}$ Again, I include month-year and province fixed effects.

Results are presented in Figure 4 which shows the estimates for each month in the

\footnotetext{
${ }^{10}$ Event times $\leq 7$ months and $\geq 13$ months are binned, see Schmidheiny and Siegloch 2020.

${ }^{11}$ Table A3 compares covariates among early- and late-treated individuals.
} 
Figure 4: Estimates of Reparations Effect on Voter Registration for Surviving Victims Receiving Reparations.Coefficient Plot.

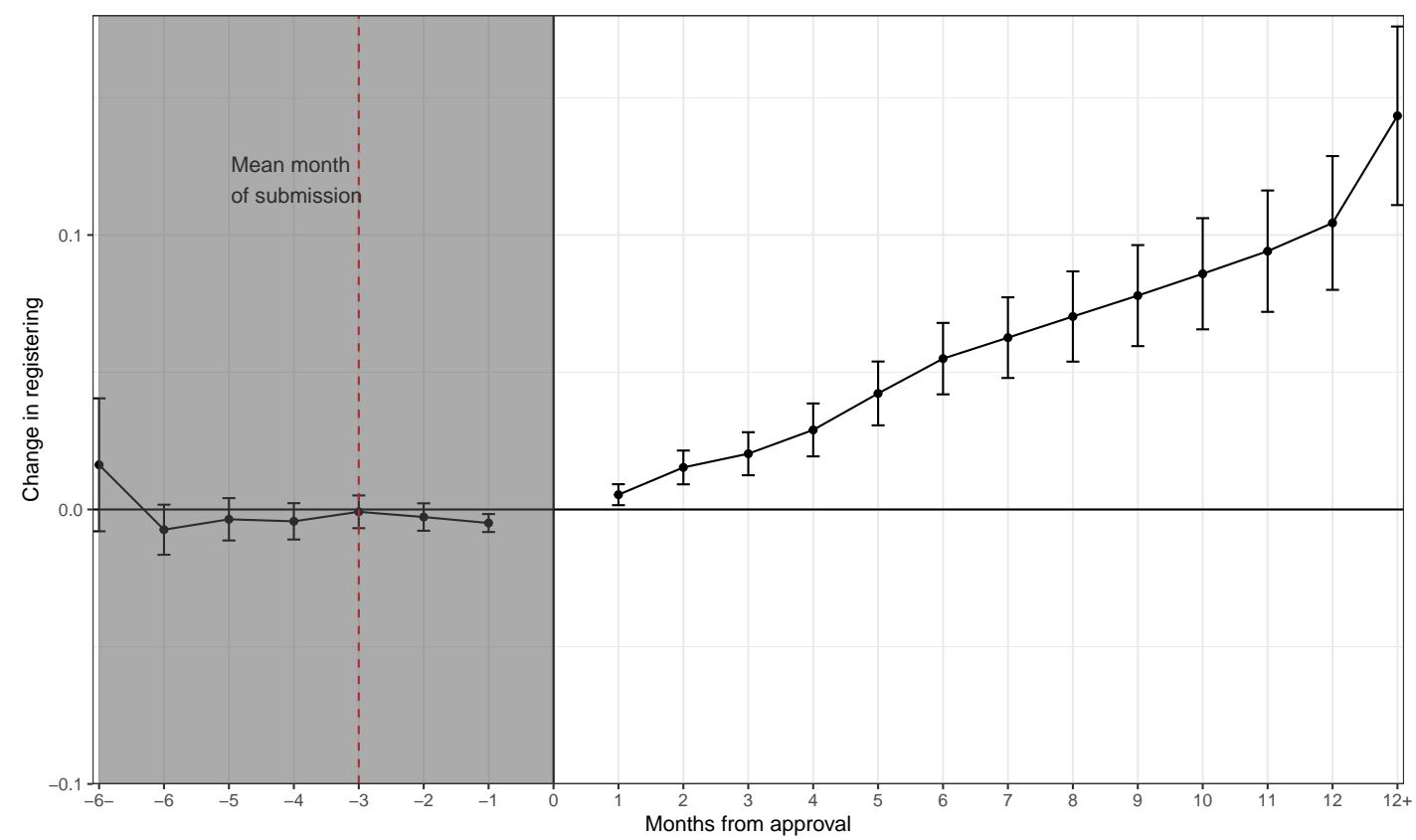

Notes: Points correspond to $\beta$ coefficients estimated from Equation 2. Heteroskedasticity Consistent Robust Standard Errors Clustered at the Individual level. Lines indicate 95\% confidence intervals. The gray area indicates the pre-treatment period. The dashed red line corresponds to the mean window when victims solicit payments from IPS (three months before approval).

specification (full results are in Table A2). First, it is important to note that the coefficient just before approval suggests a slightly negative pretrend. Though not ideal, it is reassuring that the coefficient is quantitatively small, the trend is quickly reversed, and the pre-treatment estimates are dwarfed by the downstream effects. Second, after reparations payments begin, there is a steady increase in the propensity to register to vote. After 2 months, those who received a reparation observed a 1 percentage point greater chance of registering to vote than those who had not yet been compensated. The effect increases apace until 12 months after compensation, when the effect reaches a 10 percentage point change in registering to vote after compensation. The final point shows any additional effects after 12 months, which suggests the effect reaches a 14 percentage point greater chance of voter registration and that the positive effect persists. Compared to other interventions that measure downstream voter turnout and registration, these results are quite large. Conditional cash transfers in Mexico, and face-to-face canvassing in the United States, for example, both generate about a 7 percentage point effect on turnout (De la O 2013; Gerber, Green and Nickerson 2003) and 
registration drives have yielded a 4.4\% increase (Nickerson 2015). For robustness, I use an alternative matching estimator - PanelMatch (Imai, Kim, and Wang 2019), with results in Figure A4. I also reestimate the specification with a group never treated during the panel period (but treated subsequently). ${ }^{12}$ Finally I consider a different panel period and find consistent results using a more narrow window. My findings are robust to these alternative strategies, whose results are presented in the Appendix.

I take several measures to rule out the possibility that my results are driven by politically active victims who may be more likely to both receive reparations and register to vote. First, I include only those unregistered to vote when reparations began. By focusing on this group, I omit the most politically active individuals who would have registered to vote between 1987 and 2005. Still, it could be that - even among the restricted sample of those unregistered when reparations began - because reparations are not randomly assigned, recipients could differ from nonrecipients in systematic ways. My regression specifications therefore focus on just those who claim their reparations payments (i.e. those in the white cell in Table 3), controls for individual-level covariates, and exploits variation in the date reparations payments begin. Finally, my identification strategy allows me to isolate the effect of receiving a reparations payment. The sample included here have all testified before a truth commission and solicited payments. I measure voter registration an arbitrary number of months after these events but immediately after surviving victims begin collecting compensation.

\section{Evidence of Symbolic and Economic Mechanisms}

My results show that individuals register to vote after reparations. I suggested earlier that increased participation might be driven by an economic and/or symbolic channel. The content analysis of victim testimonies showed how salient victim concerns before reparations are largely non-economic, though many do discuss material hardships. To

\footnotetext{
${ }^{12}$ See Goodman-Bacon 2021 and Callaway and Sant'Anna 2021 for an explanation of potential biases when control groups include no never-treated units
} 
Figure 5: Estimates of Relative Reparations Amount on Voter Registration. Coefficient Plot.

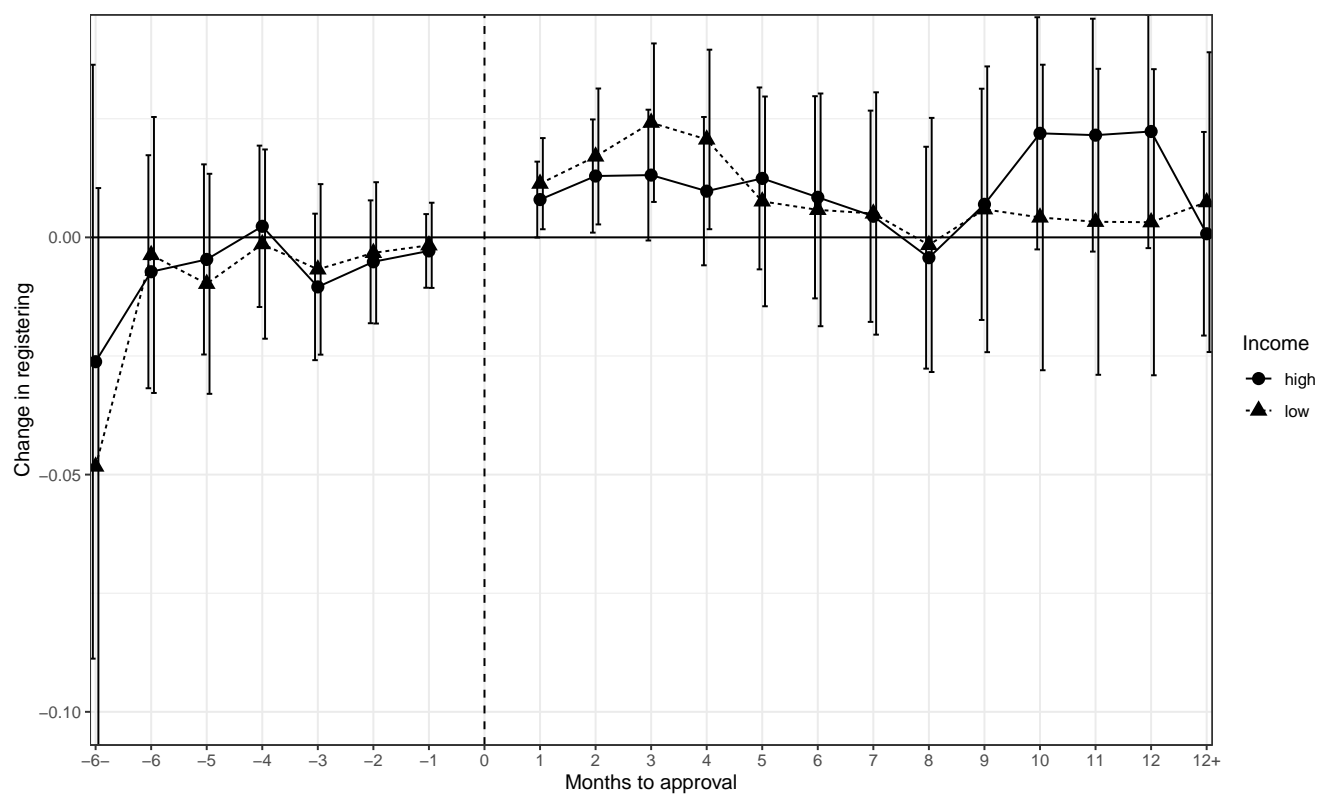

Notes: Points correspond to coefficients from event study regression for communes above and below average. Heteroskedasticity Consistent Robust Standard Errors Clustered at the Individual level. Bars indicate $95 \%$ confidence intervals.

further consider the empirical implications linked to the economic mechanism, I incorporate economic data. If registration rates increase proportionally to the relative amount of money received, this would provide support for the economic channel. Lack of a relationship might mean several things. The economic pathway might be less significant than the symbolic, but it may also be that the amount of reparations payments is too small to alter the cost of political participation. The standard of living and average income differ significantly in various Chilean communes, suggesting that the purchasing power of a reparation varies. Though reparations payments are the same amount, they would be worth relatively more in low-income communities but relatively less in high-income areas. If reparations' effect occurs by providing an economic boost, then individuals in low income communities might increase registration rates at a higher clip than those in high income communities. I utilize commune-level economic data to classify areas as above or below the average commune-level income and re-estimate Equation 2 with an interaction term between income-level and the treatment variable. The results, presented in Figure 5 show that those in low-income communities do not register at higher rates than those in medium and high-income areas. 
I next incorporate qualitative data to triangulate the quantitative analysis and consider how recipients perceive reparations and how closely perceptions align to either interpretation. I conducted 43 in-depth interviews with surviving victims and family members from August 2018 to June 2019. I recruited interviewees through collaborations with three victims' organizations and human rights lawyers representing victims. Here, I incorporate my interviews with surviving victims, the focus of the current research. My convenience sample represents a small fraction of victims - those who engage in victims' organizations and domestic prosecutions and who, like the vast majority of surviving victims, had registered to vote before receiving reparations. The quantitative analysis helps provide insight into behaviors among other victims, such as those not registered to vote before 2005. Ideally, I would have interviewed members of this group, but perhaps unsurprisingly, they are a difficult-to-reach group often uninterested in being interviewed. Despite this challenge, I attempted to speak with a range of victims with different access to reparations and other transitional justice policies. I conducted interviews in the large metropolitan areas of Santiago and Valparaíso and in the rural areas of Paine and Buin, where many participants lived in poverty. Given the prevalence of common themes among this diverse group, I expect their views to have broad applicability among other types of victims, though considering their generalizability with additional interviews remains a task for future research.

Through in-depth interviews, I sought to obtain a fuller picture of how victims view the state's response to violence and how this shaped their attitudes toward the state and their engagement in politics. I asked interviewees about their experiences with transitional justice policies in general and as recipients of reparations. Among all interviewees, the reparations process was well-known and well-understood. Respondents knew precisely how much money they were paid each month and on what day. When asked about their satisfaction with reparations, many individuals described the economic dimension of reparations to highlight how they found the policy inadequate:

“The payments make you ask 'What is justice?' The Chilean state has not been concerned with being clear or deliberate in this regard. This money 
is not a reparation, because you can't put a price on the emotional cost of losing a father." 13

"The reality of survivors from the dictatorship period is regrettable. Former prisoners are relatively elderly and many have disabilities resulting from their imprisonment and torture. And the amount of reparations is miserable, unlike other countries that have provided larger payments, like Argentina and Uruguay."14

While victims certainly do not see reparations as a complete response that fully addresses the crimes committed against them, some also describe their symbolic value:

"Before, I thought that there would be no sum of money that can repair this. And while that might not be, everything helps, especially for people who were from poor backgrounds. But the value isn't just economic; it is symbolic." 15

"The fact that there is a recognition from the state that this extermination policy existed [during the Pinochet era] and that it is symbolized by the benefits of the Rettig and Valech Commission, I think that is important."16

As Figure 6 shows, surviving victims view reparations as a positive step but an incomplete policy. When it comes to their economic dimension, two key themes emerge: 1) victims see money as incapable of addressing injustice; and 2) they believe the size of reparations payment is inadequate. Thus, though victims might have economic concerns, and many do describe consequences of victimization in economic terms, the way they discuss reparations does not suggest that the money received is sufficient to alter the cost of engaging in political activity. Instead, recipients see reparations as reliable (they are directly deposited monthly), and many note they were treated well by IPS employees, suggesting that reparations are administered with a high degree of procedural justice. Additionally, compensation appears to signify something to victims, which might drive those resistant to participate politically.

\footnotetext{
${ }^{13}$ Personal interview, conducted November 4, 2018, Santiago, Chile

${ }^{14}$ Personal interview, conducted September 4, 2018, Santiago, Chile

${ }^{15}$ Personal interview, conducted November 7, 2018, Santiago, Chile

${ }^{16}$ Personal interview, conducted November 7, 2018, Santiago, Chile
} 
Figure 6: Bar plot of qualitative interview themes.

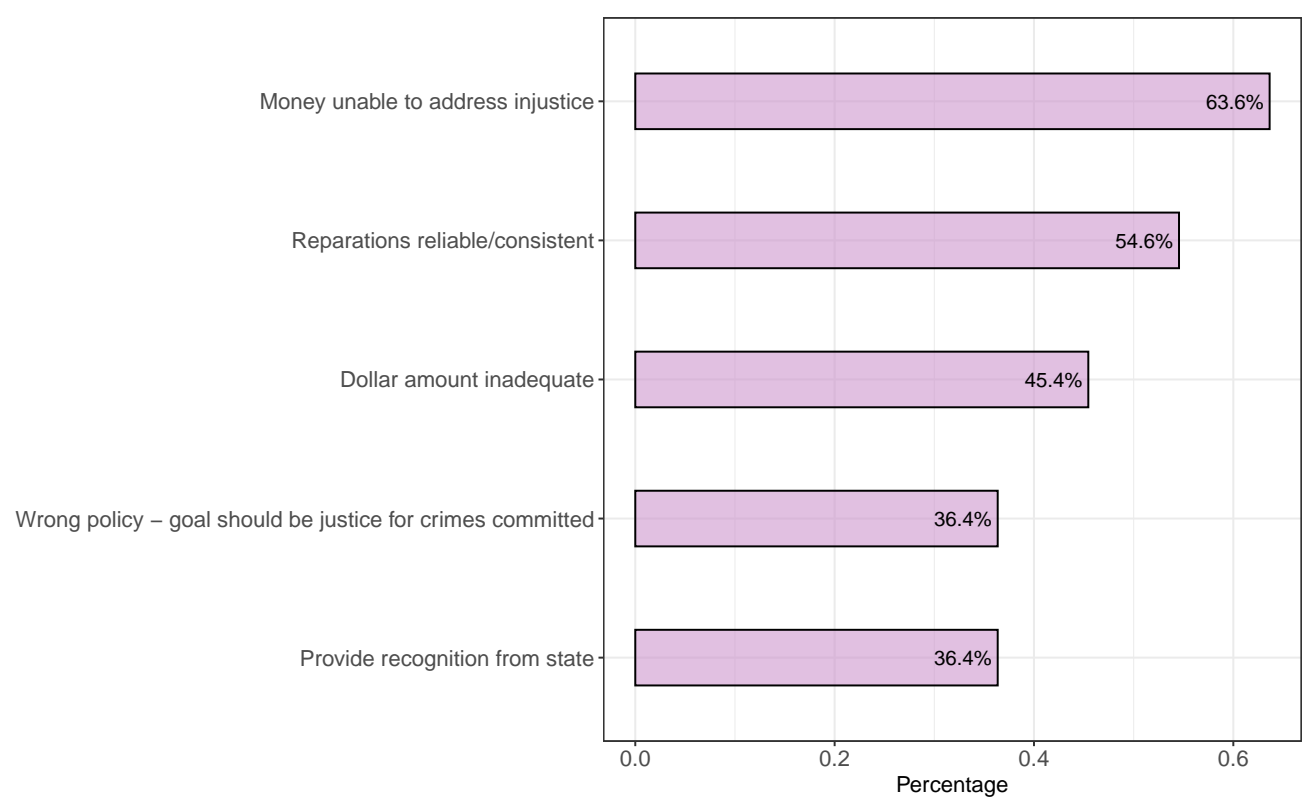

Notes: The $\mathrm{X}$-axis corresponds to the percentage of surviving victims that referenced each theme along the Y-axis during in-depth qualitative interviews conducted by the author.

As a whole, victims have economic and noneconomic concerns, but when victims discuss the economic dimension of reparations, they mainly do so in a negative way. Instead, the evidence points in favor of a symbolic mechanism: victims often frame their losses in non-economic terms and acknowledge the message behind compensation in interviews. Though I do not mean to suggest that reparations have no economic value, I do not find support for the economic mechanism in this analysis. Still, these findings warrant further research, since I cannot discern whether my lack of findings is a result of insufficient payments or the absence of an economic pathway.

\section{Evidence on demographic effects}

Before concluding, I consider possible alternative explanations to the main results presented in Figure 4. One might be concerned that those claiming reparations early versus later differ in systematic ways, obscuring the causal analysis. One way they might differ is age. It could be that those claiming reparations earlier are younger, and that these same younger folks register to vote, while older victims take longer to claim reparations and may find it more difficult to travel to voter registration sites. To 
Figure 7: Estimates of Reparations Amount on Voter Registration by Age Group. Coefficient Plot.

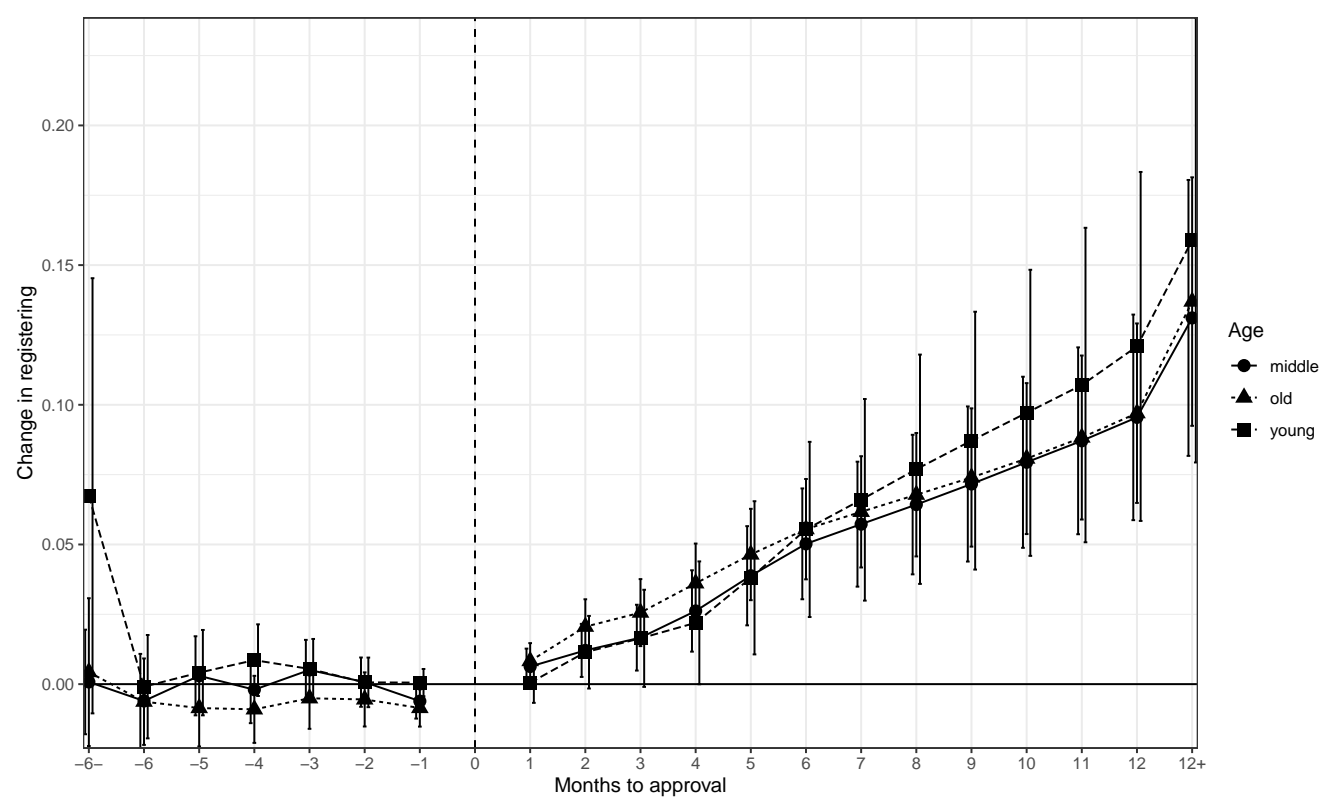

Notes: Points correspond to coefficients from separate event study regressions for subset of total sample. Heteroskedasticity Consistent Robust Standard Errors Clustered at the Individual level. Bars indicate $95 \%$ confidence intervals.

account for this counter-theory, I bin my sample into three different age groups and estimate Equation 2 separately for each. I would be concerned if the coefficients corresponding to months after treatment differed in systematic ways. As Figure 7 shows, reparations do seem to be particularly mobilizing for younger recipients. Still, older individuals' registration rates increase as well; the effect is positive and significant.

Another alternative explanation might suggest my results reflect the urban/rural divide. Because IPS offices and voter registration sites might be accessible, urban-dwelling victims could be more likely to both collect reparations and register to vote. To consider this, I utilize figures from the National Institute of Statistics and code a region "urban" if the percentage of inhabitants living in urban areas is greater than the national average (87\%). Seven regions are classified urban and seven are not. I consider these populations separately, and plot the results in Figure 8. Both groups respond to reparations; the positive coefficient is consistent across urban and rural settings. 
Figure 8: Estimates of Reparations Amount on Voter Registration by Geography. Coefficient Plot.

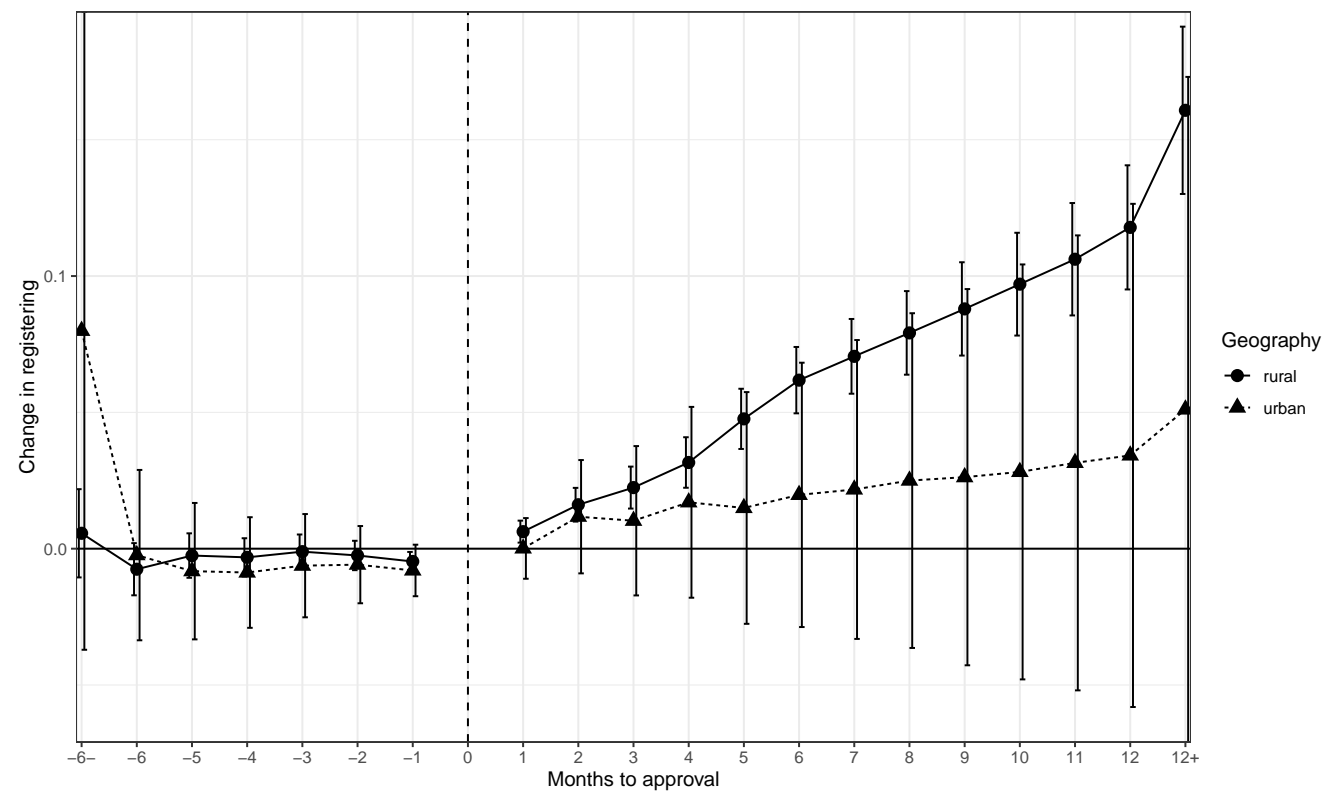

Notes: Points correspond to coefficients from separate event study regressions for subset of total sample. Heteroskedasticity Consistent Robust Standard Errors Clustered at the Individual level. Bars indicate $95 \%$ confidence intervals.

\section{Conclusions}

In this article, I suggest that a specific transitional justice policy - material reparations is associated with increased voter registration among surviving victims. Because most reparations recipients had registered to vote prior to receiving compensation, this increase is concentrated among those resistant to political participation. I highlight evidence of a symbolic mechanism, as surviving victims view reparations as acknowledgment of the crimes they suffered and demonstrate the efficacy of formal political institutions as a venue to achieve victim gains.

How might these results generalize? A unique aspect of the Chilean case is the importance of the 1988 plebiscite. In order to vote "Yes" or "No" on Pinochet's rule, Chileans had to register to vote, and $92 \%$ of the population did. The plebiscite registry served as the voting registry in the new democracy; this means that if an individual registered to vote against Pinochet, for example, she was registered to vote (and obligated to) in subsequent elections. As a result, the population whose voter registration could be affected by reparations is a small and resistant one, likely more so than in other cases. 
However, I argue that the extent to which we find effects among this population suggests that results will likely be similar - if not stronger - in other contexts.

Another feature of the Chilean case worth noting is its high degree of state capacity. Research like this is arguably only possible in such a scenario where data is collected and available. This research relies on individual-level systematic data that allows me to explore micro-dynamics between receiving reparations and registering to vote. At the same time, this feature that makes this research possible also might limit its generalizability. In the Chilean case, though there are delays between soliciting reparations and receiving approvals, they tend to be a few months. Once this period has passed, payments are dependable and consistent. The same cannot be said for cases like Colombia, where the vast majority of registered victims have not been paid. As I mentioned in the theory section, reparations could theoretically increase victims' sense of injustice; this scenario might be more likely in case like Colombia than in Chile.

This work contributes to literature examining the determinants of political participation broadly and after violence specifically: participation in transitional justice can affect political behavior and should be considered. This work shows the creation of public policies - and participation in these policies - can also have meaningful impacts on individuals' political participation. This oft-overlooked driver of political participation is relevant not just in post-violence contexts but in many situations where individuals and groups are targeted by and engaging with public policies. These results suggest that reparations can be a way to increase political participation, and that a modest monthly transfer can give voice to citizens who were previously unheard. 


\section{BIBLIOGRAPHY}

Abraham, Sarah and Liyang Sun. Forthcoming. "Estimating Dynamic Treatment Effects in Event Studies with Heterogeneous Treatment Effects." Journal of Econometrics.

Aguilar, Paloma, Laia Balcells, and Héctor Cebolla-Boado. 2011. Determinants of Attitudes Toward Transitional Justice: An Empirical Analysis of the Spanish Case. Comparative Political Studies 44(10): 1397-1430.

Bateson, Regina. 2012. Crime Victimization and Political Participation. American Political Science Review 106(3): 570587.

Bauer, Michal, Christopher Blattman, Julie Chytilová, Joseph Henrich, Edward Miguel, and Tamar Mitts. 2016. "Can War Foster Cooperation?" Journal of Economic Perspectives, 30 (3): 249-74.

Bautista, Maria Angélica. 2016. Social and Politics Effects of State-led Repression: The Chilean Case. The Pearson Institute Discussion Paper No. 27.

Belk, Russell and Melanie Wallendorf. 1990. "The sacred meanings of money." Journal of Economic Psychology 11(1): 35-67.

Bellows, John, and Edward Miguel. 2006. "War and Institutions: New Evidence from Sierra Leone."American Economic Review, 96 (2): 394-399.

Bies, R. J., \& Tripp, T. M. 1996. Beyond distrust: "Getting even" and the need for revenge. In R. M. Kramer \& T. R. Tyler (Eds.), Trust in organizations: Frontiers of theory and research (pp. 246-260). Sage Publications, Inc.

Blattman, Chris. 2009. "From Violence to Voting: War and Political Participation in Uganda." American Political Science Review 103(2): 231247.

Bradford, Ben, Kristina Murphy, and Jonathan Jackson. 2014. “Officers as mirrors: 
Policing, procedural justice and the (re)production of social identity." British Journal of Criminology 54(4): 537-550.

Brounéus, Karen. 2010. “The Trauma of Truth Telling: Effects of Witnessing in the Rwandan Gacaca Courts on Psychological Health." Journal of Conflict Resolution 54(3): 408-437.

Callaway, Brantly, and Pedro Sant'Anna. 2020. Difference-in-Differences with Multiple Time Periods. Journal of Econometrics.

Campbell, Andrea. 2003. How Politics Make Citizens: Senior Political Activism and the American Welfare State. Princeton, NJ: Princeton Univ. Press.

Carruthers, Bruce, and Wendy Espeland. 1998. "Money, Meaning, and Morality." American Behavioral Scientist 41(10): 1384-1408.

Cilliers, Jacobus, Oeindrila Dube, and Bilal Siddiqi. 2016. "Reconciling after civil conflict increases social capital but decreases individual well-being." Science 352(6287): 787-794.

Contreras, Gonzalo and Patricio Navia. 2013. “Diferencias Generacionales en la Participación Electoral en Chile, 1988-2010." Revista de ciencia política 33(2): 419-441.

Conway, Mary Margaret. 1991. Political Participation in the United States. CQ Press.

Cropanzano, Russell, Zinta Byrne, D. Ramona Bobocel, and Deborah Rupp. 2001. Moral virtues, fairness heuristics, social entities, and other denizens of organizational justice. Journal of Vocational Behavior 58: 164-209.

Dancy, Geoff and Oskar Timo Thoms. 2021. Do Truth Commissions Improve Democracy? Forthcoming in Comparative Political Studies.

David, Roman and Susanne Choi. 2005. "Forgiveness and Transitional Justice in the Czech Republic." The Journal of Conflict Resolution 50(3): 339-367. 
De Greiff, Pablo, Editor. 2008. The Handbook of Reparations. Oxford University Press.

De Juan, Alexander and Jan Henryk Pierskalla. 2016. “Civil war violence and political trust: Microlevel evidence from Nepal." Conflict Management and Peace Science 33(1): 67-88.

De la O, Ana. 2013. “Do Conditional Cash Transfers Affect Electoral Behavior? Evidence from a Randomized Experiment in Mexico." American Journal of Political Science 57(1): 1-14.

De Luca, Giacomo and Marijke Verpoorten. "Civil War and Political Participation: Evidence from Uganda." Economic Development and Cultural Change 64(1): 113-141.'

Desmet, Pieter, David De Cremer, and Eric van Dijk. 2011. On the Psychology of Financial Compensations to Restore Fairness Transgressions: When Intentions Determine Value. Journal of Business Ethics 95:105-115.

Dorff, Cassy. 2017. “Violence, kinship networks, and political resilience: Evidence from Mexico." Journal of Peace Research 54(4): 558-573.

Downs, Anthony. 1957. An economic theory of democracy. New York: Harper.

Ehlers A, Clark DM. “A cognitive model of posttraumatic stress disorder.” Behavioral Research Therapy 38(4): 319-345.

Espinoza Cuevas, Victor, María Luisa Ortiz Rojas, and Paz Rojas Baeza. 2003. Comisiones de verdad: ¿un camino incierto?: estudio comparativo de Comisiones de la Verdad en Argentina, Chile, El Salvador, Guatemala y Sudáfrica desde las víctimas y las organizaciones de derechos humanos. Santiago, Chile: Corporación de Promoción y Defensa de los Derechos del Pueblo (CODEPU).

Ferrara, Anita. 2015. Assessing the Long-Term Impact of Truth Commissions: The Chilean Truth and Reconciliation Commission in Historical Perspective. Routledge. 
Gates, Scott and Mogens K. Justesen. 2016. "Political Trust, Shocks, and Accountability: Quasi-Experimental Evidence from a Rebel Attack." Available at SSRN: https: //papers.ssrn.com/sol3/papers.cfm?abstract_id=2302163.

Galovski, Tara and Judith Lyons. 2004. "Psychological sequelae of combat violence: A review of the impact of PTSD on the veteran's family and possible interventions." Aggression and Violent Behavior 9(5): 477-201.

Gibson, James L. 2004. “Does Truth Lead to Reconciliation? Testing the Causal Assumptions of the South African Truth and Reconciliation Process." American Journal of Political Science 48(2):201-217.

—. 2006. "The Contributions of Truth to Reconciliation: Lessons from South Africa." Journal of Conflict Resolution 50(3): 309-432.

Gilligan, Michael, Benjamin Pasquale, and Cyrus Samii. 2014. "Civil war and social cohesion: Lab-in-the-field evidence from Nepal." American Journal of Political Science 58(3): 604-619.

Green, Donald, Alan Gerber, and David Nickerson. 2003. Getting Out the Vote in Local Elections: Results from Six Door-to-Door Canvassing Experiments. Journal of Politics 65(4): 1083-1096.

Goodman-Bacon, Andrew. 2021. Difference-in-Differences with Variation in Treatment Timing. Journal of Econometrics.

Hayner, Priscilla. 2001. Unspeakable Truths: Facing the Challenge of Truth Commissions. New York: Routledge.

Imai, Kosuke and In Song Kim. 2019. “When Should We Use Unit Fixed Effects Regression Models for Causal Inference with Longitudinal Data?" American Journal of Political Science 63(2): 467-490.

Imai, Kosuke, In Song Kim, and Erik Wang 2019. “Matching Methods for Causal 
Inference with Time-Series Cross-Sectional Data." Available at: https://imai.fas . harvard.edu/research/files/tscs.pdf.

Jacobs, Alan and R. Kent Weaver. 2014. "When Policies Undo Themselves: SelfUndermining Feedback as a Source of Policy Change." Governance 28(4).

Jacobson, Louis, Robert LaLonde, and Daniel Sullivan. 1993. “Earnings Losses of Displaced Workers." The American Economic Review 83(4): 685-709.

Kijewski, Sara, and Markus Freitag. 2016. "Civil War and the Formation of Social Trust in Kosovo: Posttraumatic Growth or War-Related Distress?" Journal of Conflict Resolution 62(4): 717-42.

Krueger, D. (Ed.) 1986. The Last Taboo: Money as Symbol and Reality in Psychotherapy and Psychoanalysis. New York: Bruner/Mazel.

Kruks-Wisner, Gabrielle. 2018. Claiming the State: Active Citizenship and Social Welfare in Rural India. Cambridge: Cambridge University Press.

Laplante, Lisa and Kimberly Theidon. 2007. "Truth with Consequences: Justice and Reparations in Post-Truth Commission Peru." Human Rights Quarterly 29(1): 228-250. Lawless, Jennifer and Richard Fox. 2001. "Political participation of the urban poor." Social Problems 48(3): 362-385.

Luna, Juan Pablo. 2010. “Segmented party voter linkages in Latin America: The case of the UDI." Journal of Latin American Studies 42(2): 1-30.

Luzzi, Mariana. 2014. "Pagar para reparar. Debates públicos y dilemas privados ante las políticas de reparación económica a las víctimas del terrorismo de Estado en Argentina." In Muerte, política y sociedad en la Argentina, Sandra Gayol and Gabriel Kessler (Eds): 251-276). Edhasa.

McCrary, Justin. 2007. “The Effect of Court-Ordered Hiring Quotas on the Composi- 
tion and Quality of Police." American Economic Review 97(1): 318-353.

Meares, Tracey. 2017. “Policing and procedural justice: Shaping citizens' identities to increase democratic participation." Northwestern Univ. Law Review 111: 1525-1536.

Mettler, Suzanne. 2005. Soldiers to citizens: The GI Bill and the making of the greatest generation. Oxford: Oxford University Press.

Mickel, Amy, Lisa Barron. 2008.“Getting 'More Bang for the Buck:' Symbolic Value of Monetary Rewards in Organizations." Journal of Management Inquiry 17(4): 329-338.

Miller, Ken and Andrew Rasmussen. 2009. “War Exposure, Daily Stressors, and Mental Health in Conflict and Post-Conflict Settings: Bridging the Divide Between TraumaFocused and Psychosocial Frameworks." Social Science and Medicine 70(1): 7-16.

Moncada, Eduardo. 2018. "The Politics of Criminal Victimization: Pursuing and Resisting Power." Perspectives on Politics: 1-16.

Mullen, Elizabeth and Tyler Okimoto. 2015. Compensatory justice. In R.S. Cropanzano and M.L. Ambrose (Eds). The Oxford Handbook of Justice in the Workplace. Oxford University Press.

Nickerson, David. 2015. Do Voter Registration Drives Increase Participation? For Whom and When? Journal of Politics 77(1): 88-101.

Olsen, Tricia, Leigh Payne, Andrew Reiter. 2010. Transitional Justice in Balance: Comparing Processes, Weighing Efficacy. Washington, DC: United States Institute of Peace.

Personal interviews. 2018-2019. Conducted in Santiago and Valparaiso, Chile. Transcripts available upon request.

Pham, Phuong Ngoc; Vinck, Patrick; Marchesi, Bridget; Johnson, Doug; Dixon, Peter J.; and Sikkink, Kathryn. 2016. "Evaluating Transitional Justice: The Role of MultiLevel Mixed Methods Datasets and the Colombia Reparation Program for War Vic- 
tims." Transitional Justice Review 4(1): 60-94.

Pierson, Paul. 1993. When Effect Becomes Cause: Policy Feedback and Political Change. World Politics 45(4): 595-628.

Pop-Eleches, Cristian and Grigore Pop-Eleches. 2012. “Targeted Government Spending and Political Preferences." Quarterly Journal of Political Science 7(3): 285-320.

Roberts, Margaret, Brandon Stewart, and Dustin Tingley. 2015. “stm: R Package for Structural Topic Models."

Rohner, Thoenig and Fabrizio Zilibotti. 2011. "Seeds of Distrust: Conflict in Uganda." CEPR Discussion Paper No. 8741.

Rojas, Paz, Viviana Uribe, Juanita Méndez, Carmen Gloria Díaz, and Víctor Espinoza. 2002. Pre Informe - Testimonios de Tortura en Chile. Corporación de Promoción y Defensa de los Derechos del Pueblo.

Schmidheiny, Kurt and Sebastián Siegloch. 2020. “On Event Studies and DistributedLags in Two-Way Fixed Effects Models: Identification, Equivalence, Generalization."

Sikkink, Kathryn and Carrie Booth Walling. 2007. “The Impact of Human Rights Trials in Latin America." Journal of Peace Research 44(4): 427-445.

Sikkink, Kathryn. 2011. The Justice Cascade: How Human Rights Prosecutions Are Changing World Politics. W.W. Norton \& Company.

Soss, Joe. 1999. "Lessons of Welfare: Policy Design, Political Learning, and Political Action." The American Political Science Review 93 (2): 363-80.

Sveaass, Nora and Anne Margrethe Sønneland. 2015. "Dealing with the past: Survivors' perspectives on economic reparations in Argentina." International Perspectives in Psychology: Research, Practice, Consultation 4(4): 223-238.

Tyler, Tom and Steven Blader. 2003. The Group Engagement Model: Procedural Jus- 
tice, Social Identity, and Cooperative Behavior. Personality and Social Psychology Review 7(4): 349-361.

Tyler, Tom and Edgar Allan Lind. 1988. The Social Psychology of Procedural Justice. Plenum Press.

Valech (National Commission on Political Imprisonment and Torture) Report. 2004.

Valech (National Commission on Political Imprisonment and Torture) Report. 2010.

Valenzuela, Samuel and Timothy Scully. 1997. "Electoral Choices and the Party System in Chile: Continuities and Changes at the Recovery of Democracy." Comparative Politics 29(4): 511-527.

Verba, Sidney, Norman Nie, and Jae-On Kim. 1978. Participation and Political Equality: A Seven National Comparison. New York: Cambridge University Press.

Viaene, Lieselotte. 2010. “Life is priceless: Mayan Q'eqchi' Voices of the Guatemalan Reparations Program." The International Journal of Transitional Justice 4: 4-25.

Voytas, Elsa and Ben Crisman. 2021. "State Violence and Participation in Transitional Justice: Evidence from Colombia." Unpublished working paper.

Weaver, Vesla and Amy Lerman. 2010. "Political Consequences of the Carceral State." American Political Science Review 104(4): 817-833.

Wielbelhaus-Brahm. 2010. Truth commissions and transitional societies: The impact on human rights and democracy. New York: Routledge.

Zelizer, Viviana. 1989. “The Social Meaning of Money: 'Special Monies."' American Journal of Sociology 95(2): 342-377.

—. 1994. "The social meaning of money." Princeton, NJ: Princeton University Press. 


\title{
APPENDIX
}

\author{
Reparations Details
}

Table A1: Monthly reparation amounts.

\begin{tabular}{c|c|c|c}
\hline Category & Chilean Pesos & USD & $\%$ of min wage \\
\hline Surviving victim (under 70) & $\$ 184,407$ & $\$ 259.84$ & $46 \%$ \\
Surviving victim (70-74) & $\$ 201,636$ & $\$ 284.11$ & $51 \%$ \\
Surviving victim (75 and up) & $\$ 211,053$ & $\$ 297.38$ & $53 \%$ \\
Relative (1 beneficiary) & $\$ 557,590$ & $\$ 785.67$ & $176 \%$ \\
Relative ( $>1$ beneficiary) & $\$ 780,628$ total & $1,099.94$ & $248 \%$ \\
\hline
\end{tabular}

Notes: 2016 amounts from Leyes Reparatorias de Derechos Humanos Informe. These amounts are disbursed monthly. Conversions via Google Finance, 20 August 2019.

Full regression results

Table A2 presents results from Equation 2. 
Table A2: Modeling the Effects of Reparations on Voter Registration

\begin{tabular}{|c|c|}
\hline \multicolumn{2}{|c|}{ Outcome: Registering to Vote } \\
\hline$\beta_{-6}$ & $\begin{array}{r}-0.007 \\
(0.005)\end{array}$ \\
\hline$\beta_{-5}$ & $\begin{array}{r}-0.004 \\
(0.004)\end{array}$ \\
\hline$\beta_{-4}$ & $\begin{array}{r}-0.004 \\
(0.003)\end{array}$ \\
\hline$\beta_{-3}$ & $\begin{array}{r}-0.001 \\
(0.003)\end{array}$ \\
\hline$\beta_{-2}$ & $\begin{array}{r}-0.003 \\
(0.003)\end{array}$ \\
\hline$\beta_{-1}$ & $\begin{array}{c}-0.005^{* *} \\
(0.002)\end{array}$ \\
\hline$\beta_{1}$ & $\begin{array}{l}0.005^{* *} \\
(0.002)\end{array}$ \\
\hline$\beta_{2}$ & $\begin{array}{l}0.015^{* * *} \\
(0.003)\end{array}$ \\
\hline$\beta_{3}$ & $\begin{array}{l}0.020^{* * *} \\
(0.004)\end{array}$ \\
\hline$\beta_{4}$ & $\begin{array}{l}0.030^{* * *} \\
(0.0045\end{array}$ \\
\hline$\beta_{5}$ & $\begin{array}{l}0.042^{* * *} \\
(0.006)\end{array}$ \\
\hline$\beta_{6}$ & $\begin{array}{l}0.055^{* * *} \\
(0.007)\end{array}$ \\
\hline$\beta_{7}$ & $\begin{array}{l}0.063^{* * *} \\
(0.007)\end{array}$ \\
\hline$\beta_{8}$ & $\begin{array}{l}0.070^{* * *} \\
(0.008)\end{array}$ \\
\hline$\beta_{9}$ & $\begin{array}{l}0.078^{* * *} \\
(0.009)\end{array}$ \\
\hline$\beta_{10}$ & $\begin{array}{l}0.086^{\text {*** }} \\
(0.010)\end{array}$ \\
\hline$\beta_{11}$ & $\begin{array}{l}0.094^{* * *} \\
(0.011)\end{array}$ \\
\hline$\beta_{12}$ & $\begin{array}{c}0.10^{* * *} \\
(0.012)\end{array}$ \\
\hline$\beta_{12+}$ & $\begin{array}{c}0.14^{* * *} \\
(0.017)\end{array}$ \\
\hline Age & $\begin{array}{l}0.0007^{* * *} \\
(0.000)\end{array}$ \\
\hline Female & $\begin{array}{c}-0.007^{* * *} \\
(0.011) \\
\end{array}$ \\
\hline Province FE & Yes \\
\hline Year Month FE & Yes \\
\hline Individuals & 5,213 \\
\hline$R^{2}$ & 0.093 \\
\hline
\end{tabular}

Notes: Rows correspond to coefficients from respective variables. Heteroskedasticity Consistent Robust Standard Errors Clustered at the Individual level in parentheses. 


\section{Covariate balance}

Table A3 compares those treated before and after the median approval date. 
Table A3: Early-vs. late-treatment group balance

\begin{tabular}{lccc}
\hline Variable & Early & Late & $p$-value \\
\hline Year of birth & 1951 & 1953 & 0.29 \\
Gender & $19 \%$ Female & $19 \%$ Female & 0.96 \\
Urban/rural & $14.9 \%$ & $14.3 \%$ & 0.92 \\
\hline
\end{tabular}

${ }^{*} p<0.05 ;{ }^{* *} p<0.01 ;{ }^{* * *} p<0.001$

Notes: Rows correspond to covariates among sample split at median reparations approval date. $P$-value reported from t-tests on variable in associated row. 


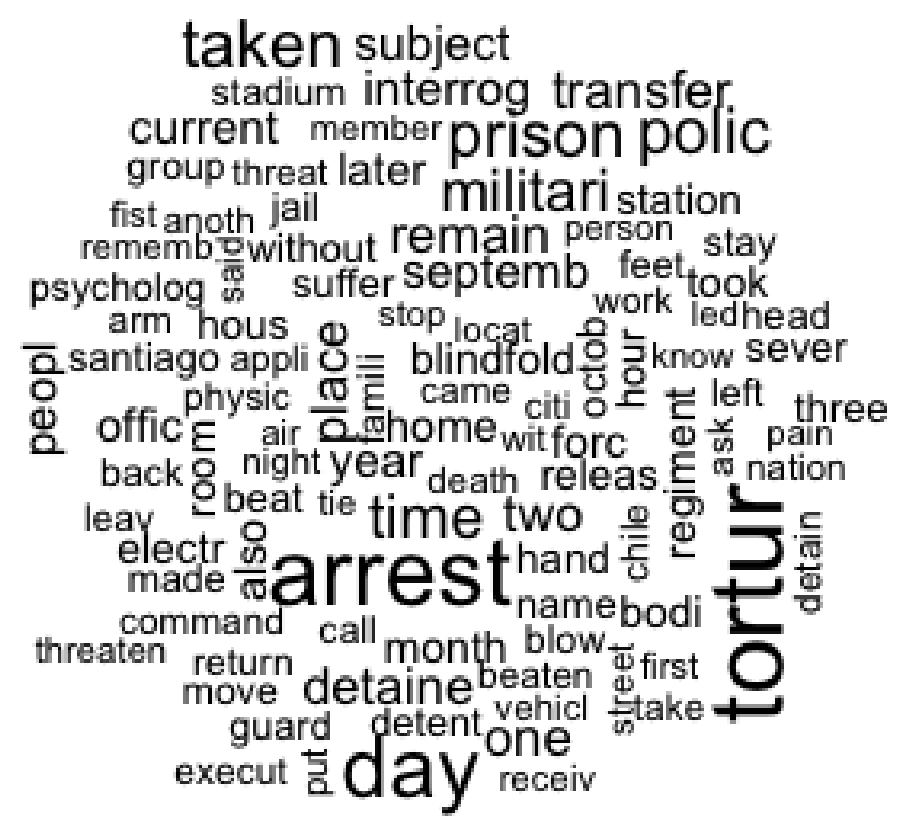

Notes: Testimonies from Corporación de Promoción y Defensa de los Derechos del Pueblo (CODEPU) "Testimonios de Tortura en Chile" accessed in the Museo de la Memoria y los Derechos Humanos Centro de Documentación (CEDOC), Santiago, Chile.

Text Analysis

\section{Word cloud}

To describe the content of victim testimonies, I utilize automated text analysis. I construct a word cloud (Figure A1) which visually presents prevalent words used in the testimonies. I also use a structural topic model (STM) to discover topics commonly addressed by victims in their testimonies (Roberts et al. 2015). This approach considers each document to be comprised of a mixture of topics, and the structural topic model estimates topical prevalence. Appendix Figure A2 displays the expected proportion of the corpus from a 20-topic STM model.

\section{Testimony structural topic model}

Structural topic models estimate the prevalence of topics contained in the textual cor- 
Figure A2: Structural Topic Model.

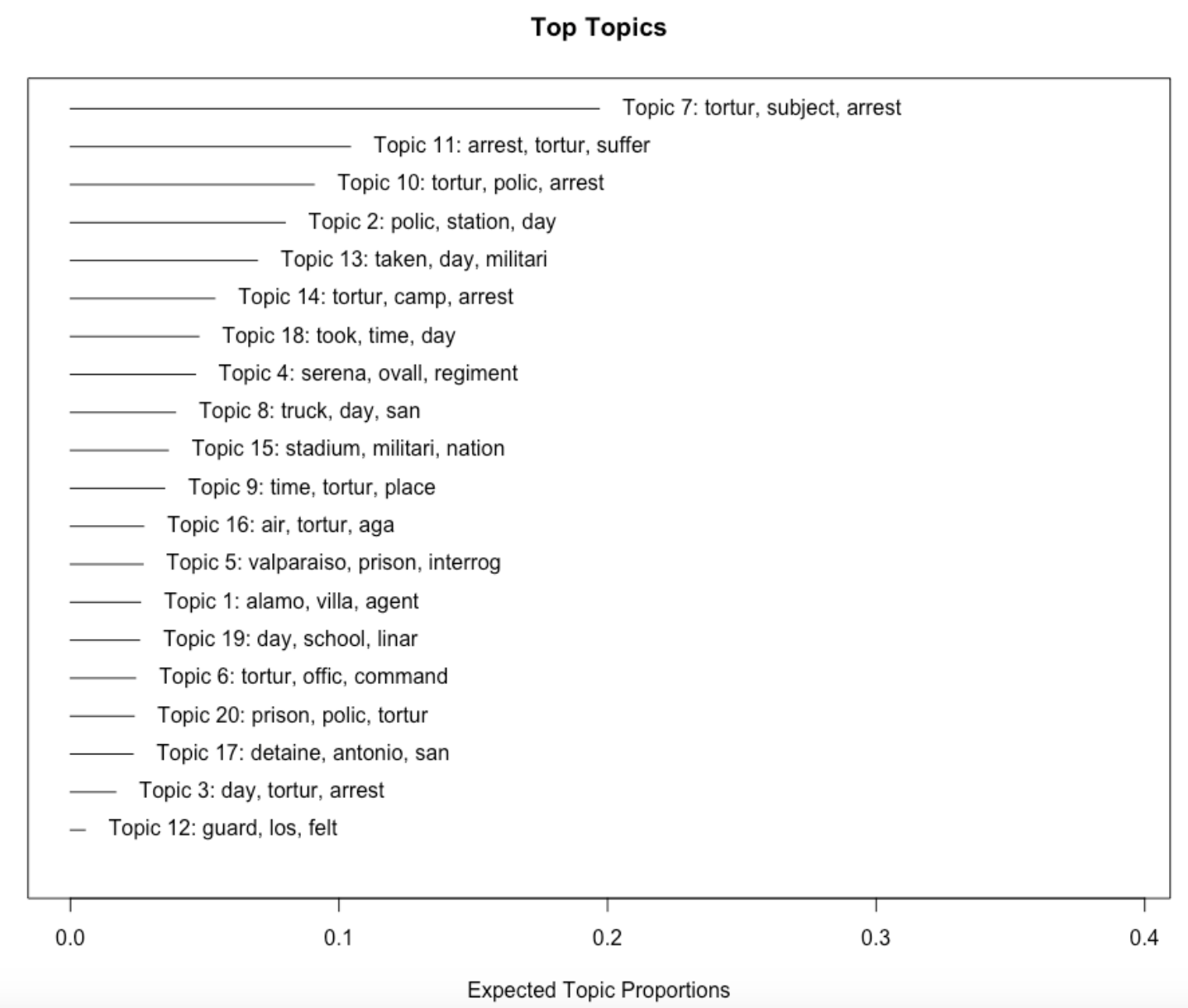

Note: Top 20 topics estimated from structural topic model on corpus of torture testimonies. Testimonies from CODEPU "Testimonios de Tortura en Chile" accessed in the Museo de la Memoria y los Derechos Humanos Centro de Documentación (CEDOC), Santiago, Chile.

pus. The top topics are presented in A2 along with the topical content, or prevalent words, for each top topic. The model is estimated using the stm package in $\mathbf{R}$ (Roberts et al. 2015).

\section{Examples of testimonies coded as economic}

Below are additional snippets of testimonies that were coded as economic, meaning that the testimony authors framed the consequences of torture as economic in nature.

"I lost my job and was then unable to help my parents who depended on me..." 
"The greatest suffering was borne by my children who were 6 and 4 years old. They were left homeless without money, without medical assistance, etc. Little by little my wife sold the furniture to buy food for them."

"I lost my only job up to that point. After that, I had to work odd jobs. If I'd kept my job, I'd have a full pension and never would have had these economic troubles..."' 
All victims listed in the final Valech truth commission report are eligible to receive compensation but must certify their eligibility in-person at an IPS office to begin receiving payments. According to IPS, 1,261 surviving victims (about 5\% of those still living) are eligible to receive a reparations payment, but have not received reparations. ${ }^{17}$ Do surviving victims who receive reparations behave differently than those who don't? Figure A3 plots each group's survival function, showing registration trends among those who are eligible but are not receiving reparations (in light grey) and those who are receiving reparations (in dark grey).

The plot shows an initial separation between the two groups of victims; it appears reparations' recipients register to vote relatively soon after compensation begins. Over time, the gap increases, suggesting that among these resistant individuals, reparations might have an effect. Both groups experience periodic jumps in registration rates which correspond to periods preceding national elections. Of course, one might question the comparability of these two groups. I address this possibility in the next section.

To begin exploring the dynamics between receiving reparations and registering to vote, I plot the cumulative probability of voter registration for surviving victims who receive and do not receive reparations. I use a non-parametric estimator to compute each group's "survival function," defined as:

$$
F(t)=\operatorname{Prob}(\tau \leq t)
$$

where $t=0,1, \ldots$ is the time in days and $\tau$ is a random variable indicating whether or not the event of voter registration has taken place. This model is often used to measure how long patients survive after certain health treatments. Here, it estimates the probability that an unregistered recipient registers to vote over time.

\footnotetext{
${ }^{17}$ Many others listed have died and therefore do not appear in my reparations data.
} 
Figure A3: Survival plot of victims receiving versus not receiving reparations payments.

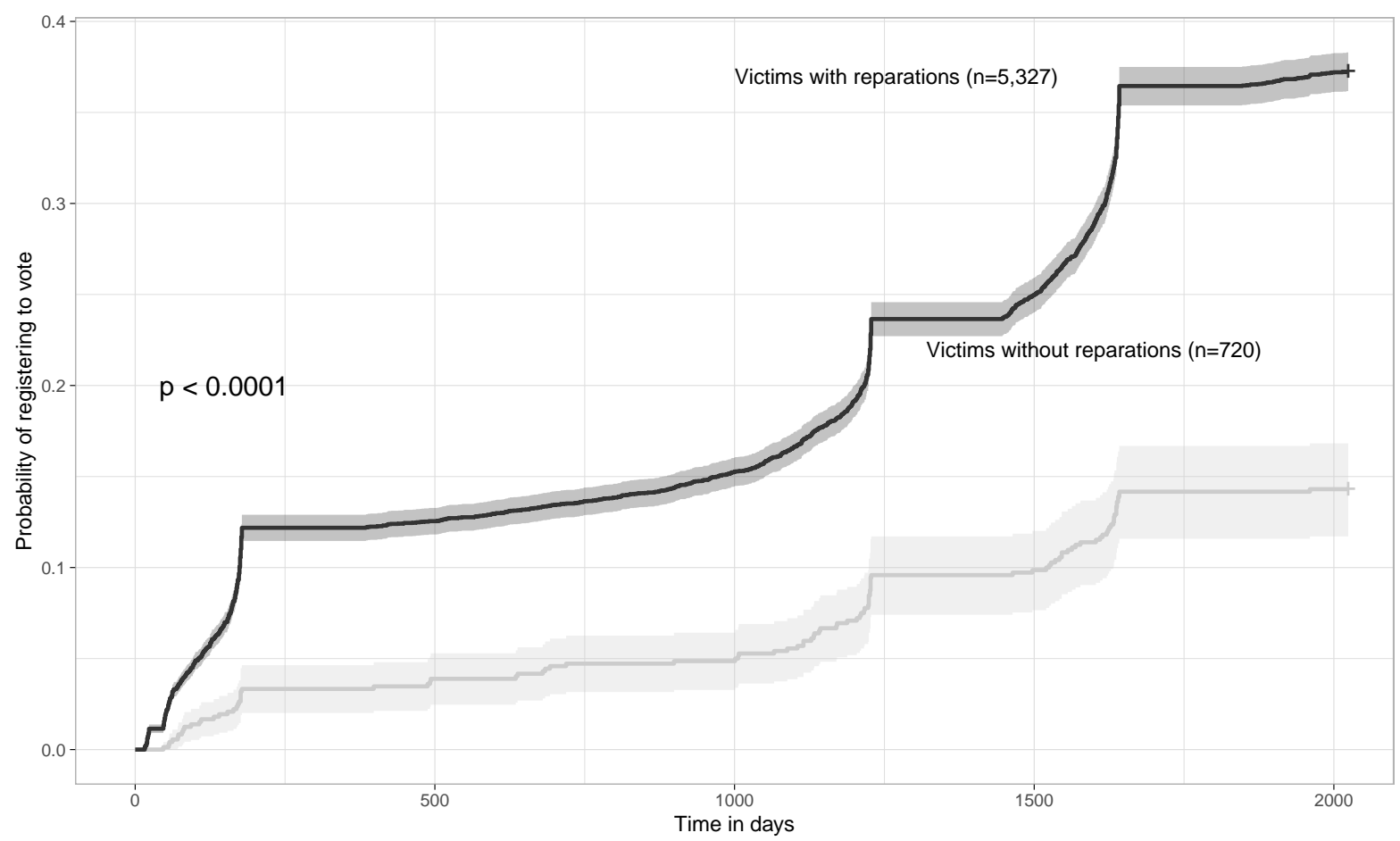

Notes: The Y-axis corresponds to the probability that an individual registers to vote while the $\mathrm{X}$-axis represents days that have passed since reparations began. Light grey line corresponds to victims eligible for but not receiving reparations; dark grey line corresponds to victims receiving reparations. P-value from logrank test. Data received from Instituto de Previsión Social.

\section{Panel Match Results}

For robustness, I consider the main analyses in the paper in using a matching estimator that pairs observations based on covariates and similar treatment histories using the PanelMatch package in $\mathbf{R}$ using covariate balance propensity score matching (Imai, Kim, and Wang 2019). Figure A4 shows results. Standard errors are computed using bootstrap estimation $(n=1,000)$. Though the point estimates are somewhat smaller than those found in the paper's main specification (Equation 2), the direction and significance of the effects persist, adding confidence to the notion that registration rates increase after receiving compensation. 
Figure A4: Panel Match Estimates of Reparations on Voter Registration.

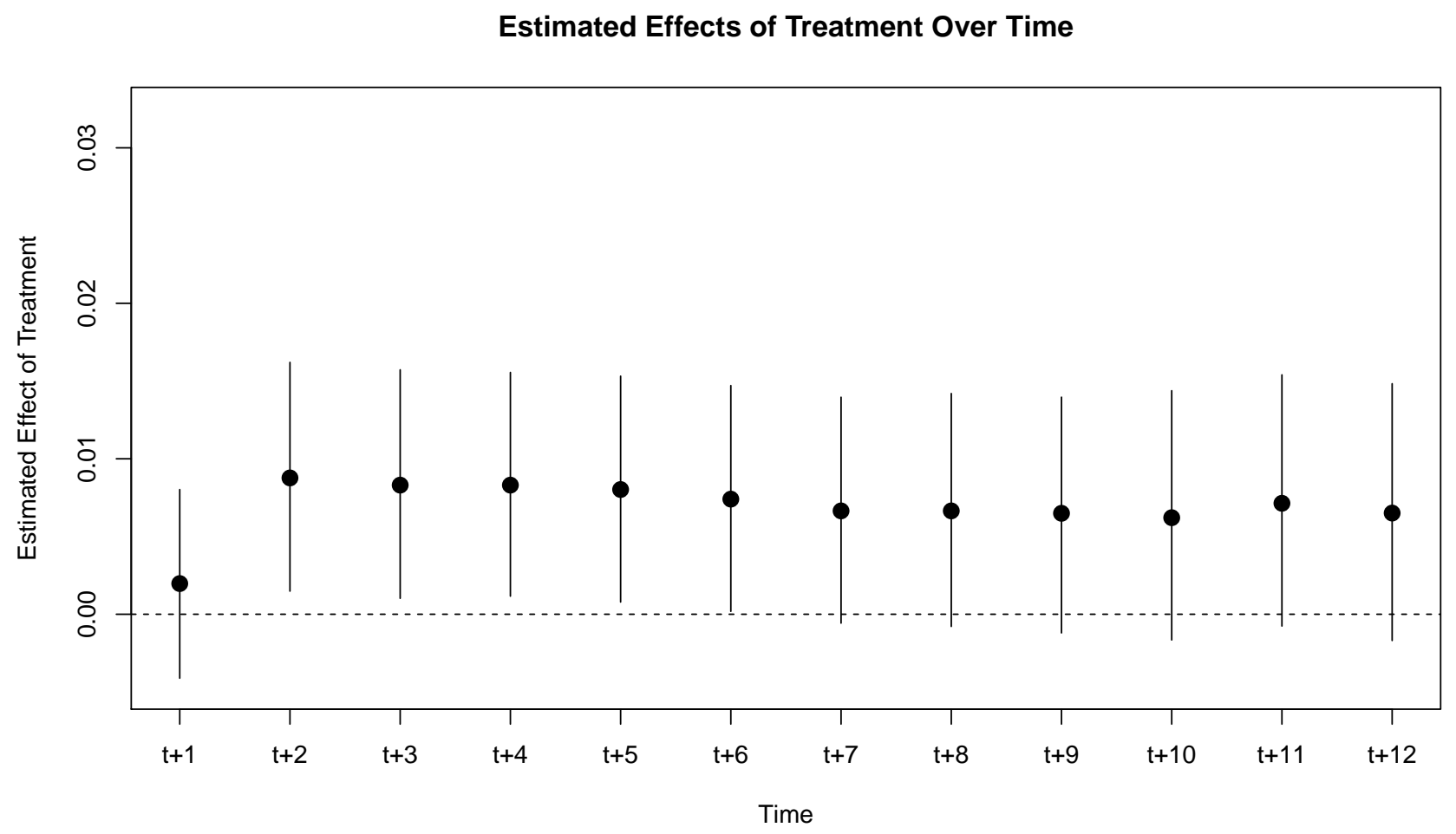

Notes: Points correspond to PanelMatch estimates. Lines indicate $95 \%$ confidence intervals. 
Figure A5: Estimates of Reparations on Voter Registration for Surviving Victims Receiving Reparations with Pure Control Group. Coefficient Plot.

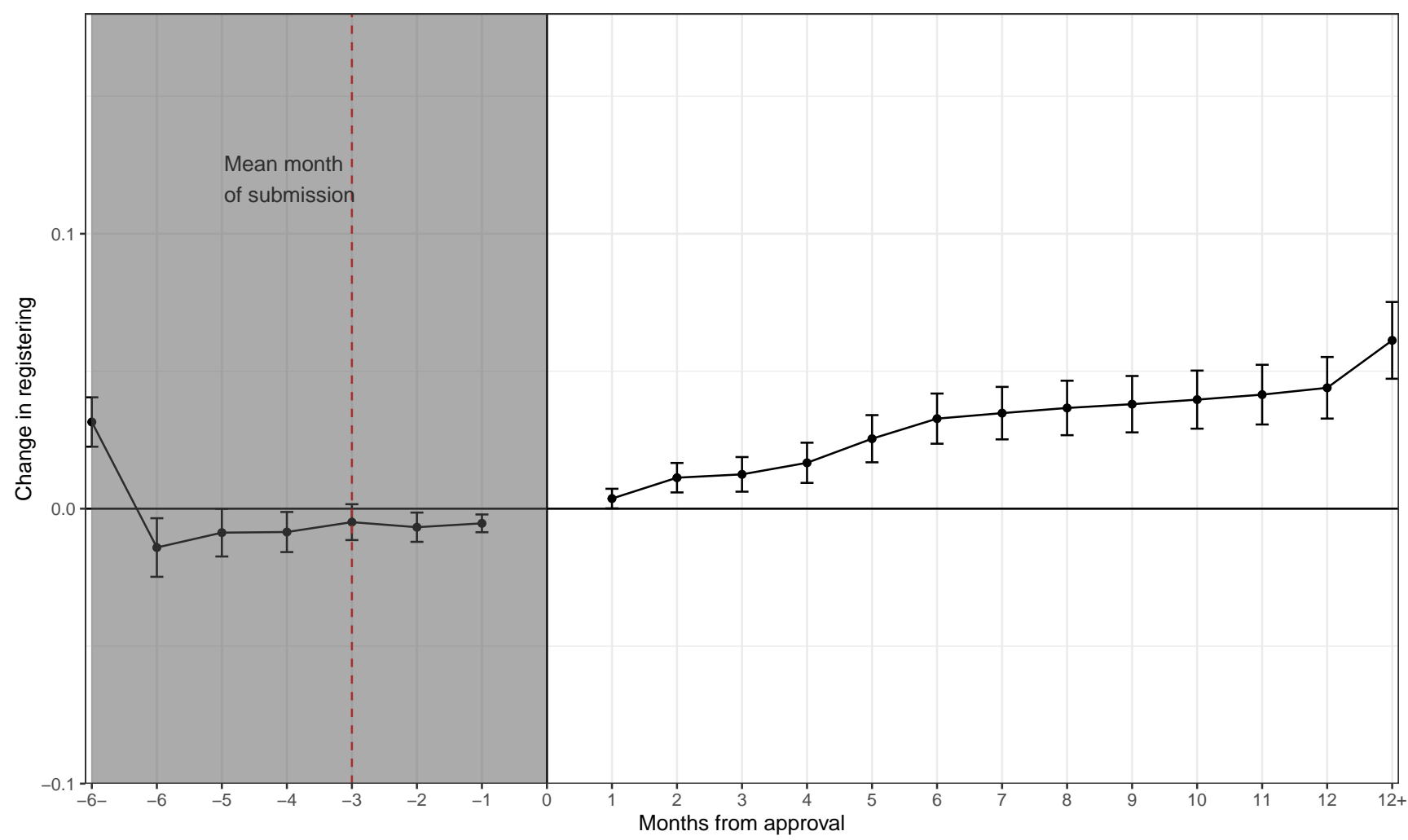

Notes: Points correspond to $\beta$ coefficients estimated from Equation 2. Heteroskedasticity Consistent Robust Standard Errors Clustered at the Individual level. Lines indicate 95\% confidence intervals. The gray area indicates the pre-treatment period. The dashed red line corresponds to the mean window when victims solicit payments from IPS (three months before approval).

\section{Estimation with pure control}

Recent work highlights potential risks when carrying out an event study without no never treated units (see e.g. Chaisemartin and D'Haultfoeuille 2020; Abraham and Sun 2020; Imai and Kim 2019). For robustness, I reestimate Equation 2, but add individuals who receive compensation after the panel period but who are unregistered to vote at the start of the panel period. These individuals remain untreated for the entire period where treatment effects are estimated. The results from Figure A5 suggest similar patterns to those presented in the main text, though the results level out sooner at about $5 \%$. The direction and significance of the effects persist, adding confidence to the notion that registration rates increase after receiving compensation. 
Figure A6: Estimates of Reparations on Voter Registration for Surviving Victims Receiving Reparations. Coefficient Plot.

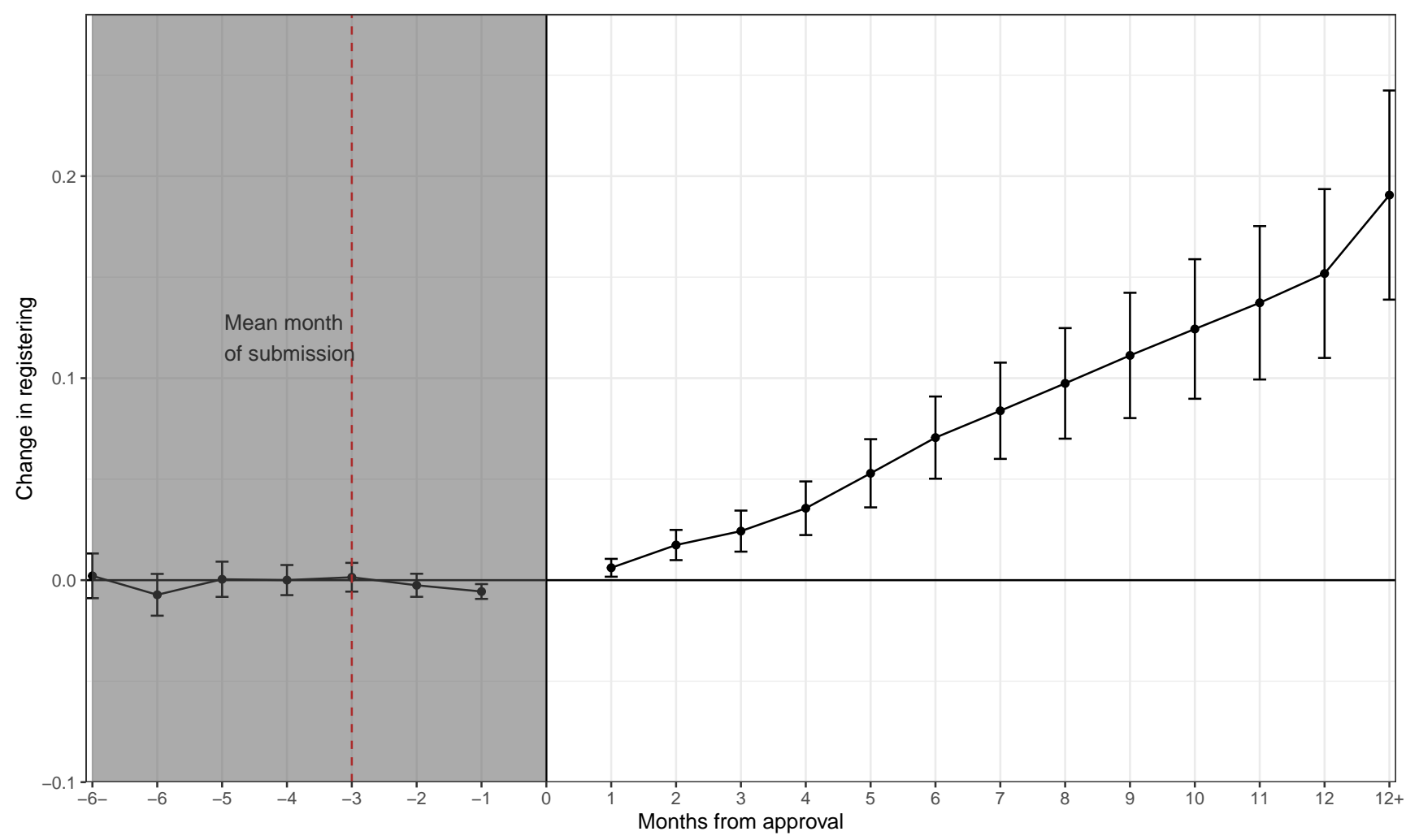

Notes: Points correspond to $\beta$ coefficients estimated from Equation 2. Heteroskedasticity Consistent Robust Standard Errors Clustered at the Individual level. Lines indicate 95\% confidence intervals. The gray area indicates the pre-treatment period. The dashed red line corresponds to the mean window when victims solicit payments from IPS (three months before approval).

\section{Estimation with subsample}

For robustness, I estimate the model on a monthly panel ending in 2006 after many requests have been approved. Results, in Figure A6, are generally consistent with the main ones presented in the body of the paper.

\section{Additional interview information}

Table A4: Descriptive statistics of interview subjects.

\begin{tabular}{c|c|c|c} 
Population & Total & Male & Female \\
\hline Surviving victims & 13 & 5 & 8 \\
\hline Family members & 30 & 5 & 25 \\
\hline
\end{tabular}

